$$
\begin{aligned}
& \text { 震 } \\
& \overline{\overline{\bar{N}}}
\end{aligned}
$$

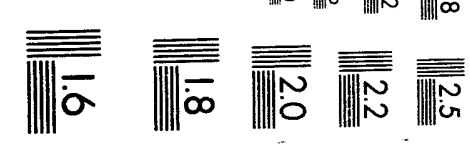



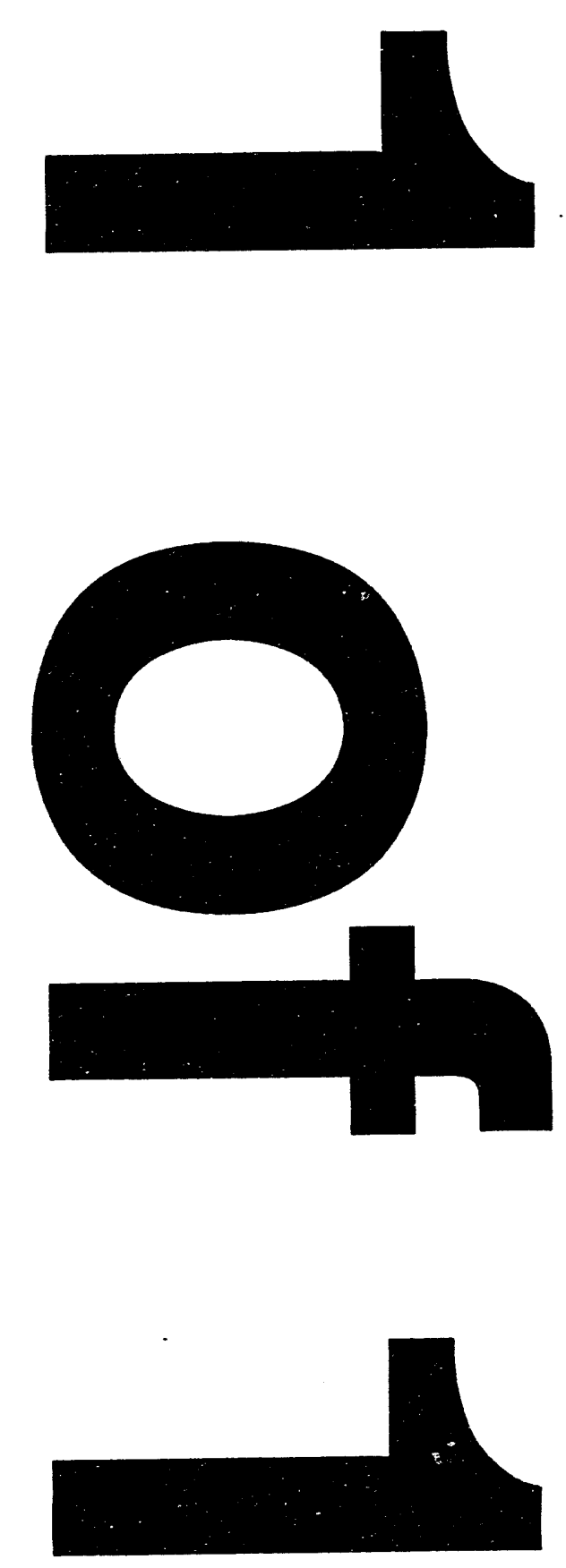
Distribution Category:

High-Level Radioactive Waste

Disposal in Tuff

(UC-814)

ANL-92/48

\section{ARGONNE NATIONAL LABORATORY \\ 9700 South Cass Avenue \\ Argonne, Illinois 60439-4837}

\section{TEST PLAN FOR REACTIONS BETWEEN SPENT FUEL AND $\mathrm{J}$-13 WELL WATER UNDER UNSATURATED CONDITIONS}

by

P. A. Finn, D. J. Wronkiewicz, J. C. Hoh,

J. W. Emery, L. D. Hafenrichter, and J. K. Bates

Chemical Technology Division

January 1993

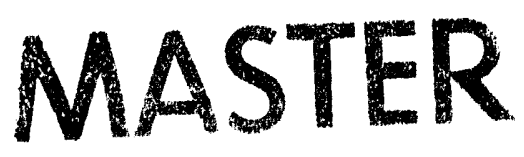




\section{TABLE OF CONTENTS}

\section{Page}

ACRONYMS $\ldots \ldots \ldots \ldots \ldots \ldots \ldots \ldots \ldots \ldots \ldots \ldots \ldots \ldots \ldots \ldots \ldots \ldots \ldots$ vi

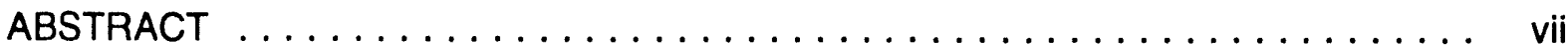

$1.0 \quad$ INTRODUCTION $\ldots \ldots \ldots \ldots \ldots \ldots \ldots \ldots \ldots \ldots \ldots \ldots \ldots \ldots \ldots$

1.1 Background $\ldots \ldots \ldots \ldots \ldots \ldots \ldots \ldots \ldots \ldots \ldots \ldots, 1$

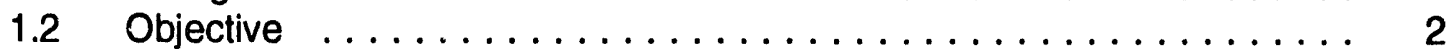

2.0 TEST DESCRIPTION $\ldots \ldots \ldots \ldots \ldots \ldots \ldots \ldots \ldots \ldots \ldots \ldots \ldots \ldots$

$2.1 \quad$ Test Matrices $\ldots \ldots \ldots \ldots \ldots \ldots \ldots \ldots \ldots \ldots \ldots \ldots \ldots, 4$

2.1.1 Water as a Parameter ................... 5

2.1.2 Oxygen Content - Radiolysis Effects ............. 6

2.1.3 Fuel Burnup $\ldots \ldots \ldots \ldots \ldots \ldots \ldots \ldots \ldots \ldots, 7$

2.1.4 Fuel Surface Area $\ldots \ldots \ldots \ldots \ldots \ldots \ldots \ldots \ldots 7$

2.1.5 Temperature $\ldots \ldots \ldots \ldots \ldots \ldots \ldots \ldots \ldots \ldots \ldots, 8$

2.2 Sample Selection, Preparation, and Identification $\ldots \ldots \ldots \ldots \ldots .8$

2.2.1 Fuel and Cladding . . . . . . . . . . . . . . . . . 8

$2.2 .2 \mathrm{~J}-13$ Water $\ldots \ldots \ldots \ldots \ldots \ldots \ldots \ldots \ldots \ldots \ldots, 8 \ldots \ldots$

2.2.3 Other Test Materials $\ldots \ldots \ldots \ldots \ldots \ldots \ldots \ldots \ldots \ldots, 9$

2.3 Equipment Description $\ldots \ldots \ldots \ldots \ldots \ldots \ldots \ldots \ldots \ldots, 9$

2.3.1 Test Vessel and Associated Equipment . . . . . . . . . . . 9

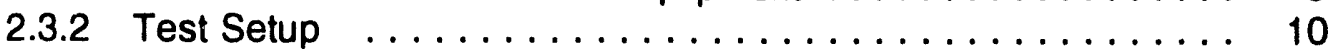

2.3.3 Test Operation $\ldots \ldots \ldots \ldots \ldots \ldots \ldots \ldots \ldots \ldots \ldots, 10 \ldots \ldots$

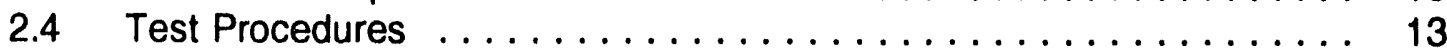

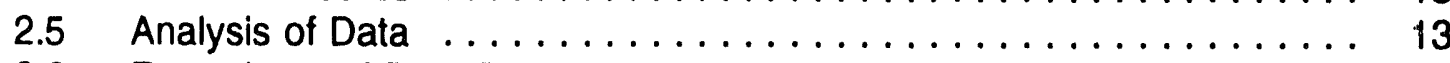

2.6 Reporting and Data Recording $\ldots \ldots \ldots \ldots \ldots \ldots \ldots \ldots \ldots$

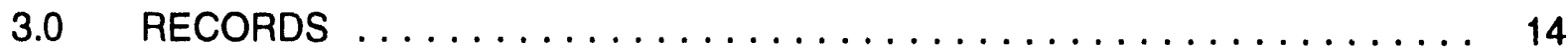

3.1 Detailed Records $\ldots \ldots \ldots \ldots \ldots \ldots \ldots \ldots \ldots \ldots \ldots \ldots, 14$

3.2 Identification $\ldots \ldots \ldots \ldots \ldots \ldots \ldots \ldots \ldots \ldots \ldots \ldots, 15$

4.0 QUALITY ASSURANCE $\ldots \ldots \ldots \ldots \ldots \ldots \ldots \ldots \ldots \ldots \ldots \ldots \ldots \ldots$

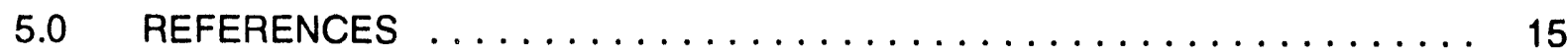

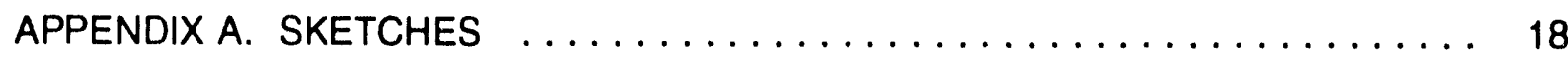

APPENDIX B. MATRICES FOR SOLUTION SAMPLES FOR SPENT

FUEL UNSATURATED TESTS $\ldots \ldots \ldots \ldots \ldots \ldots \ldots \ldots \ldots \ldots \ldots$

APPENDIX C. TEST PLAN: SURFACE REACTIONS BETWEEN EJ-13 WATER AND $\cup \mathrm{O}_{2}$ PELLETS UNDER UNSATURATED CONDITIONS AT $90^{\circ} \mathrm{C} \ldots \ldots 23$ 


\section{LIST OF FIGURES}

Page

1. Test Vessel Configuration $\ldots \ldots \ldots \ldots \ldots \ldots \ldots \ldots \ldots \ldots \ldots \ldots$

2. Test Injection System $\ldots \ldots \ldots \ldots \ldots \ldots \ldots \ldots \ldots \ldots \ldots \ldots \ldots \ldots$

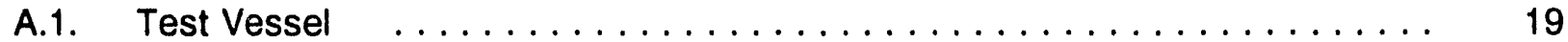

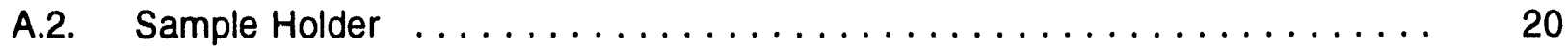




\section{LIST OF TABLES}

Page

1. Characteristics of Irradiated $\mathrm{UO}_{2} \ldots \ldots \ldots \ldots \ldots$

2. Matrix I: Spent Fuel at $9 \varrho^{\circ} \mathrm{C}$, Unsaturated Conditions $\ldots \ldots \ldots \ldots$

3. Composition of EJ-13 Water $(\mu \mathrm{g} / \mathrm{mL}) \ldots \ldots \ldots \ldots$

4. Required Measurements During Unsaturated Testing $\ldots \ldots \ldots \ldots \ldots$

B.1. Sample Matrix for Vapor and Low Injection Rate Tests $\ldots \ldots \ldots \ldots 21$

B.2. Sample Matrix for a High Injection Rate Test $\ldots \ldots \ldots \ldots \ldots \ldots$ 


\section{ACRONYMS}

$\begin{array}{ll}\text { ACL } & \text { Analytical Chemistry Laboratory at CMT } \\ \text { ANL } & \text { Argonne National Laboratory } \\ \text { ASTM } & \text { American Society for Testing and Materials } \\ \text { ATM } & \text { Approved Testing Material } \\ \text { CMT } & \text { Chemical Technology Division at ANL } \\ \text { DIW } & \text { Deionized Water } \\ \text { EBS } & \text { Engineered Barrier System } \\ \text { HLW } & \text { High-Level Waste } \\ \text { ICP } & \text { Inductively Coupled Plasma } \\ \text { LLNL } & \text { Larence Livermore National Laboratory } \\ \text { LPAS } & \text { Laser-Induced Photo-Acoustic Spectroscopy } \\ \text { MCC } & \text { Materials Characterization Center } \\ \text { MS } & \text { Mass Spectrometry } \\ \text { NIST } & \text { National Institute of Science and Technology } \\ \text { NNWSI } & \text { Nevada Nuclear Waste Storage Investigation } \\ \text { PNL } & \text { Pacific Northwest Laboratory } \\ \text { PWR } & \text { Pressurized Water Reactor } \\ \text { QA } & \text { Quality Assurance } \\ \text { SEM } & \text { Scanning Electron Microscopy } \\ \text { SFL } & \text { Spent Fuel Leaching } \\ \text { SP } & \text { Spent Fuel } \\ \text { YMP } & \text { Yucca Mountain Site Characterization Project }\end{array}$




\title{
TEST PLAN FOR REACTIONS BETWEEN SPENT FUEL AND \\ J-13 WELL WATER UNDER UNSATURATED CONDITIONS
}

\author{
P. A. Finn, D. J. Wronkiewicz, J. C. Hoh,
}

J. W. Emery, L. D. Hafenrichter, and J. K. Bates

\begin{abstract}
Two complementary test plans are presented, one to examine the reaction of spent fuel and $\mathrm{J}-13$ well water under unsaturated conditions and the second to examine the reaction of unirradiated $\mathrm{UO}_{2}$ pellets and $\mathrm{J}-13$ well water under unsaturated conditions. The former test plan examines the importance of the water content, the oxygen content as affected by radiolysis, the fuel burnup, fuel surface area, and temperature. The latter test plan examines the effect of the non-presence of Teflon in the test vessel.
\end{abstract}




\section{TEST PLAN FOR REACTIONS BETWEEN SPENT FUEL AND $J-13$ WELL WATER UNDER UNSATURATED CONDITIONS}

\subsection{INTRODUCTION}

This task is performed under the guidance of the Yucca Mountain Site Characterization Project (YMP) and is part of activity D-20-43 as indicated in the YMP/LLNL Spent Fuel Scientific Investigation Plan.

The YMP is evaluating the long-term performance of a high-level nuclear waste form, spent fuel from commercial reactors. Permanent disposal of the spent fuel is possible in a potential repository to be located in the volcanic tuff beds near Yucca Mountain, Nevada. During the post-coniainment period the spent fuel could be exposed to water condensation since some of the cladding is assumed to fail during this time. Spent fuel leach (SFL) tests are designed to simulate and monitor the release of radionuclides from the spent fuel under this condition.

This Test Plan addresses the anticipated conditions whereby spent fuel is contacted by small amounts of water that trickle through the spent fuel container. The type of information derived from these tests includes as key outputs the degradation rate of spent fuel (this includes dissolution, selective leaching, and physical processes that may alter the spent fuel under repository conditions as distinguished from basic dissolution kinetics testing in support of model development), the release rate of radionuclides from the spent fuel, the solution chemistry of liquid in contact with the spent fuel, and the chemistry and mineralogy of altered spent fuel and secondary minerals that form on the surface of spent fuel under simulated repository conditions. These key outputs are recorded as a function of the total time of reaction.

\subsection{Background}

Two types of saturated tests have been done to measure the dissolution of spent fuel in a saturated water environment. The first, static water immersion tests at 25 and $85^{\circ} \mathrm{C}$, was done with different configurations of spent fuel [1-5] using either site-specific J-13 well water or deionized water. The second, dynamic flow-through tests on $\mathrm{UO}_{2}$ at $25^{\circ} \mathrm{C}$ [6-7] and on spent fuel at $25-75^{\circ} \mathrm{C}[8]$ were described. In both types of tests a slow dissolution of the spent fuel matrix was observed and the actinide solubility limit appeared to be a function of matrix dissolution.

An unsaturated test [9], e.g., a drip test, has been developed to measure radionuclide release in an unsaturated water environment. The $0.075 \mathrm{~mL}$ water injection rate as specified in the Unsaturated Test Procedure is equivalent to a water infiltration rate of $0.5 \mathrm{~mm} / \mathrm{yr}$. The unsaturated test has been applied to the testing of unirradiated $\mathrm{UO}_{2}$ pellets [10]. In these tests $\mathrm{UO}_{2}$ pellets have been reacted with small drops of $\mathrm{J}-13$ water, equilibrated with Topopah tuff. Secondary uranyl phases were formed at the reaction surface. Also, a pulse of uranium release occurred $\sim 1$ to 2 years into the test period as measured by periodic analyses of the test solutions. 
Since unsaturated conditions are anticipated in the repository, results from unsaturated tests with spent fuel will be used to (1) identify important processes that will affect spent fuel performance and radionuclide release rates under unsaturated conditions, (2) provide data that can be used to validate models that predict the long-term behavior of spent fuel within the repository, and (3) provide information regarding the distribution of radionuclides in solution.

\section{$1.2 \quad$ Objective}

The objective of this task is to use unsaturated tests to measure the reactivity of spent fuel under a range of potential repository conditions. Data from the tests are expected to yield information on the (1) chemistry of the solutions after contact with the spent fuel as a function of time, (2) the dissolution rate of the spent fuel matrix, (3) the form of the released radionuclides, (4) the release rate of the radionuclides, and (5) the type of alteration products formed as a function of total reaction time.

The ANL/CMT tests will provide information that can be useful to the YMP in characterizing spent fuel performance. This information will be used to identify important spent fuel degradation modes in the validation of predictive models and in interactions with the thermodynamic data base development task to identify needed speciation studies. The information derived from these tests will be used to help develop predictive models and will provide a technical basis for the determination of the source term for radionuclide release from exposed spent fuel contained in failed cladding in a tuff repository. This information will be required during the NRC licensing process.

This tests will determine: (1) the effect of different spent fuel types with varied bumup, gas release characteristics and oxidation state, (2) the effect of different types of water environments, (3) the effect of the oxygen $\left(\mathrm{O}_{2}\right)$ content, (4) the effect of radiolysis products on speciation of radionuclides, (5) the effect of reaction temperature, and (6) the effects of fuel surface area. The reactivity of spent fuel will be determined by measuring solution composition, the type and extent of secondary phase formation, and gas evolution as a function of time.

\subsection{TEST DESCRIPTION}

Tests are planned with different types of spent fuels, i.e., those with a burnup range from 20 to $\geq 60 \mathrm{MWd} / \mathrm{kgU}$ with potentially different degrees of oxidation. Two well characterized spent fuels, ATM-103 and ATM-106 will be the first tested. Some of the characteristics of these two fuels are shown in Table 1. This Test Plan will describe the initiai tests in detail and will discuss future tests in general. Future tests will depend in part on the results obtained in the initial tests.

In the initial tests, the spent fuel will be exposed to $\mathrm{J}-13$ water equilibrated with Topopah tuff, which is designated as EJ-13 water. For most tests, EJ-13 water will be, periodically dripped on spent fuel specimens at water injection rates of $0.075 \mathrm{~mL}$ or $0.75 \mathrm{~mL}$, each being injected every 3.5 days. A separate test, designated as a reference, will have a 
Table 1. Characteristics of Irradiated $\mathrm{UO}_{2}$

\begin{tabular}{||l|c|c||}
\hline \hline Characteristic & ATM-103 & ATM-106 \\
\hline \hline Initial Density (\%TD) & $94.4-95.6$ & $91.7-94.0$ \\
\hline Burnup (MWd/kgU) & 30 & 43 \\
\hline Discharge Date & $10 / 80$ & $04 / 82$ \\
\hline Fission Gas Release (\%) & $<1$ & 10 \\
\hline Grain Size $(\mu \mathrm{m})$ & $>5$ & $>10$ \\
\hline Pellet Height $(\mathrm{cm})$ & 1.14 & 1.651 \\
\hline Pellet Diameter $(\mathrm{cm})$ & 0.9563 & 0.965 \\
\hline Cladding Thickness $(\mathrm{cm})$ & 0.066 & 0.066 \\
\hline
\end{tabular}

gas sampling system as part of the test vessel and will be injected at a rate of $0.075 \mathrm{~mL}$. Gas samples will be taken as indicated by an increase in pressure. A control test, one which does not contain spent fuel, will have water injected at the $0.075 \mathrm{~mL}$ rate to verify that the leach solutions are not contaminated by either actinides or fission products and to account for the effect of the stainless steel vessel on the chemistry of the solutions. In addition, saturated vapor tests will be done with spent fuei, tests in which an atmosphere of saturated water vapor is present but no liquid water is injected.

Each test will be done in an air-tight stainless steel vessel in an oven held at a fixed temperature. The initial tests will be done at $90^{\circ} \mathrm{C}$; later tests will be done at $150^{\circ} \mathrm{C}$ as a method of accelerating reaction processes. Since the vessels used for the initial tests are partially closed systems, the oxygen concentration may be partially depleted as the initial tests progress.

The solutions will be characterized $(\mathrm{pH}$, cation and anion content, elemental composition, radionuclide speciation between dissolved and suspended material) periodically and at test termination. At test termination, the spent fuel samples and/or the alteration products wilı also be characterized ( $\mathrm{X}$-ray diffraction, Auger, electron-microprobe, metallography, TEM, SEM, etc.). The results will be compared with those from unsaturated tests with unirradiated $\cup_{2}$ and those from saturated tests with spent fuel. The results will also be compared with the calculated results from the EQ3/6 model.

The configuration in the unsaturated tests will consist of spent fuel inside a Zircaloy-4 cladding tube which rests on a Zircaloy-4 support stand. The base of the Zircaloy support stand will contain a $20 \mu \mathrm{m}$ thick Zircaloy-4 filter to separate the leached solution from contact with the spent fuel. 


\section{$2.1 \quad$ Test Matrices}

Three test matrices, I, II, III, are planned. The main purpose of matrix I, shown in Table 2, will be to evaluate the feasibility of doing these types of tests to obtain information on the behavior of the spent fuel. The tests will apply methods of speciation to solutions and will characterize secondary phases to determine the important parameters in an unsaturated water environment. This initial test series will be used to evaluate how to do the tests and to establish that there is consistency in the results. This will be a limited set of tests, but the number will be sufficient to establish the methodology. Crushed fuel will be used because of its availability.

The purpose of matrix II is to extend the tests described in matrix I and to include an expanded set of fuel types and conditions. For example, fuels with a wider burnup range, fuels with a range of oxidation aging, different cladding materials and container materials, other EBS (Engineered Barrier System) components, rock tuff (to evaluate radionuclide interactions), water drip rates, and oxygen content will be included. These tests will expand on the knowledge gained in the initial matrix of tests and will be used for validation purposes. Many of these tests will be done when the configuration of the EBS is known.

The purpose of matrix III is to perform accelerated tests at $150^{\circ} \mathrm{C}$ since accelerated tests are an important component of the ASTM leach test format. These tests will not evaluate actual repository conditions, but will accelerate reactions that occur at lower temperatures. The tests will be done as saturated vapor tests or drip tests.

The initial test matrix, that is shown in Table 2, will include three test sets using two types of spent fuel, plus a test with additional instrumentation designated as a reference test, and a control test. In each test set the two PWR fuels, ATM-103 and ATM-106, to be used will have different burnups, different fission gas releases, and different grain sizes but both will be tested as fragmented materials. The results from a test set, e.g., S3-1J1 and S6-1J1, in which the only variable parameter will be the fuel type should provide insight on the importance of this parameter on radionuclide release and the extent of fuel alteration.

Table 2. Matrix I: Spent Fuel at $90^{\circ} \mathrm{C}$, Unsaturated Conditions

\begin{tabular}{|l|l|l|l||}
\hline Test Number $^{\text {a }}$ & Fuel & Water Form & Inject Rate/3.5 d \\
\hline \hline S3-1J1 & ATM-103 & Inject & $0.075 \mathrm{~mL}$ \\
\hline S6-1J1 & ATM-106 & Inject & $0.075 \mathrm{~mL}$ \\
\hline S3-2J1 & ATM-103 & Inject & $0.75 \mathrm{~mL}$ \\
\hline S6-2J1 & ATM-106 & Inject & $0.75 \mathrm{~mL}$ \\
\hline S3-V1 & ATM-103 & Vapor & $\cdots$ \\
\hline S6-V1 & ATM-106 & Vapor & $\cdots$ \\
\hline CC-1J1 & None & Inject & $0.075 \mathrm{~mL}$ \\
\hline R6-1J1 & ATM-106 & Inject & $0.075 \mathrm{~mL}$ \\
\hline
\end{tabular}

${ }^{a}$ The test number will be explained in Section 3.2. 
Tests S3-1J1 and S3-2J1, which have injection rates with a ten-fold range, $0.075 \mathrm{~mL}$ and $0.75 \mathrm{~mL}$, respectively, will be done to show the effect of periodic additions of small amounts of liquid water to the surface alteration of the spent fuel. The large range will be used to demonstrate that there was sufficient liquid to react with the spent fuel since we are concerned about maintaining sustained water contact in the unsaturated tests. The available spent fuel has a high radiation field which causes heating and potential evaporation of the dripped water; therefore, we have one test with an increased water volume. In the repository, the radiation field will be a factor of 100 lower so evaporation will not prevent prolonged water contact. See Section 2.1.1 for additional information.

The reference test, R6-1J1, will be used to measure the pressure rise in the test vessel during a test cycle and to obtain a sample of the gases present due to radiolysis, of hydrogen and perhaps (NO) $x$ species. The fission gases released from the spent fuel may also be determined if fuel alteration is significant. This experiment will permit one to determine the exient to which radiolysis changes the environment of the test and also the nature of the gaseous radiolysis products. Both solution analyses and surface alteration products identified from tests S6-1J1 and R6-1J1 will be compared to ensure that the introduction of additional instrumentation does not affect test results.

The nature of the alteration products formed in the tests with saturated water vapor, S3-V1 and S6-V1, will be compared to those in which liquid water is injected, S3-1J1 and S3-2J1, and S6-1J1 and S6-2J1. The tests with saturated water vapor will provide information as to the alteration of the spent fuel prior to contact with liquid water. Alteration under saturated water vapor conditions may give different results than under water injection conditions. Also, the alteration under saturated water vapor conditions may give different results than inose observed under unsaturated vapor conditions. In addition, the composition of the solutions in the two different tests will be compared to determine the extent that radiolysis products condensed in the solutions affect their chemical composition.

The duration of the tests will depend on the nature of the observed reactions, but each test will be designed as a long-term test ( $\geq 2$ years) based on experience with unsaturated tests with unirradiated $\mathrm{UO}_{2}$. The test solutions will be examinerl periodically at monthly intervals for elemental analysis and at six-month intervals for speciation, etc. The alteration products formed on the spent fuel will be examined at the termination of the test, which may be greater than 2 years.

The necessity for a given test will depend on test results from previous test matrices. The test matrices will be recorded in the Scientific Notebook. Any changes in a matrix during the tests will be documented in the Scientific Notebook.

\subsubsection{Water as a Parameter}

Three water environments will be present in these tests, a saturated water vapor atmosphere, a water drip rate of $0.075 \mathrm{~mL}$, and a water drip rate of $0.75 \mathrm{~mL}$. Two issues were considered in having the three water environments, (1) the amount of evaporation which would occur due to the decay heat of the spent fuel, and (2) the effect of a higher water drip rate in the repository, i.e., one a facior of ten higher than that associated with an infiltration of $0.5 \mathrm{~mm} / \mathrm{yr}$. 
The decay heat produced by one pellet $(11.6 \mathrm{~g})$ of 10 -yr-old ATM-106 fuel is of the order of 0.017 watt [11], and arises primarily from fission products. This corresponds to $60 \mathrm{~J} / \mathrm{h}(0.057 \mathrm{BTU} / \mathrm{h})$. Using this as a heat source, the temperature rise at the pellet surface was calculated using three representative heat transfer coefficients, 4.1, 6.1, and $10 \mathrm{~J} /\left(\mathrm{h} \mathrm{cm}{ }^{\circ}{ }^{\circ} \mathrm{C}\right)$. The temperature rise was $2.6,1.7$, and $1^{\circ} \mathrm{C}$, respectively, all sufficient to evaporate the water drops injected at the fuel surface. To establish a worse case, the minimum time required to evaporate the injected water was calculated for each injection rate; it is $10.2 \mathrm{~s}$ for the $0.075 \mathrm{~mL}$ drop and $102 \mathrm{~s}$ for the $0.75 \mathrm{~mL}$ drop. The higher injection rate thus permits water to percolate and/or diffuse into the spent fuel. For these limiting cases, most of the water may not percolate down through the spent fuel. However, these are boundary calculations and ignore factors such as surface tension and the presence of saturated water vapor.

The tests in which no liquid water will be injected will be used to evaluate the roie of saturated water vapor in the alteration of spent fuel, i.e., the tests may demonstrate enhanced oxidation of the spent fuel.

\subsubsection{Oxygen Content - Radiolysis Effects}

One concern in the initial tests is the oxygen content in the test vessel. The formation of alteration products is limited by the amount of oxygen present. The moles of $\mathrm{UO}_{2}$ present in one ATM-106 pellet is 0.049 . The minimum oxygen needed to convert $1 \%$ of the $\mathrm{UO}_{2}$ to $\mathrm{U}_{4} \mathrm{O}_{9}$ is $6.2 \times 10^{-5}$ moles. Oxygen content is also a concern in the repository; however, information for the repository is not available.

Since the test vessels will be sealed, the maximum amount of oxygen present will be that dictated by the geometric constraints of the tesi vessel and that introduced during each water injection. The test vessel volume when empty will be $\sim 60 \mathrm{~mL}$, so the maximum amount of oxygen present at room temperature in an air environment will be $5 \times 10^{-4}$ moles. As the total amount of water injected into the vessel increases, the vessel free volume will decrease, and since the vessel will be vented, the total oxygen content will decrease. The amount of oxygen introduced each 3.5 days during an injection is $7 \times 10^{-6}$ moles, the amount in $500 \mu \mathrm{L}$ of air. This amount will not appreciably increase the total oxygen content in the vessel.

The effect of radiolysis of water, liquid and vapor, within the test vessel was considered, specifically for its effect on the oxygen content. The radiolysis products from water will be hydrogen gas and hydrogen pernxide. However, the $G$ value for water varies not only with the form of the water but also with the form of the radiation. For gamma radiation, the $\mathrm{G}\left(\mathrm{H}_{2}\right)$ for liquid water is 0.43 molecules/100 eV [12]; that for vapor is 0.02 [13]. For alpha radiation, the $G\left(H_{2}\right)$ for liquid water is 2 [14]; that for vapor is 5.9. The gamma radiation field of 10-year-old fuel is ten times greater than the alpha radiation fie!d. However, the alpha radiation field will not decrease appreciably in the repository during the time period of interest and the $\mathrm{G}\left(\mathrm{H}_{2}\right)$ for alpha radiation is $\sim 10$ times that for gamma radiation; therefore, the amount of radiolysis products generated, i.e., hydrogen, from gamma radiation in these proposed tests will simulate the potential effects of alpha radiolysis on the solution chemistry and on the formation of alteration products in the repository. 
The maximum amount of hydrogen produced from radiolysis of liquid water by gamma irradiation in these tests will be $7.5 \times 10^{-10} \mathrm{moles} / \mathrm{s}$ or $6.5 \times 10^{-5} \mathrm{moles} / \mathrm{d}$; that from vapor will be twenty times less and is ignored. Since the maximum amount of oxygen in the vessel is $5 \times 10^{-4}$ moles, the introduction of significant amounts of hydrogen due to water radiolysis is an issue of concern. In 30 days, if recombination does not occur, the hydrogen content could be $2 \times 10^{-3}$ moles, which could result in a lower oxygen potential at the fuel surface.

The effect of the radiation field on the nitrogen in the test vessel atmosphere was considered. The radiolysis product will be nitrate, $\mathrm{NO}_{3}{ }^{\circ}$, a species which incorporates oxygen and which can decrease the $\mathrm{pH}$ of water. Oxygen depletion could result, but this could not be quantified since either the oxygen atmosphere or by-products from water radiolysis could be the oxygen source. If the $\mathrm{pH}$ of the solution and/or that at the fuel surface decreases, the speciation of ions in solution will change, as will the alteration products formed.

Other materials in the test vessel which could react with the available oxygen are the Zircaloy-4 test stand and the inner wall of the stainless steel vessel. To evaluate the amount of oxygen which might react with these surfaces, the moles of material was estimated: 0.24 moles for Zircaloy -4 , and $\sim 0.29$ moles for a stainless steel layer $0.13 \mathrm{~cm}$ thick. If $0.01 \%$ of these surfaces reacted with oxygen, one would use $6 \times 10^{-5}$ moles of oxygen.

If one includes the test vessel volume, the effects of radiolysis, oxidation of vessel surfaces, and the requirements of stoichiometric oxidation of $\mathrm{UO}_{2}$, tests done in a static atmosphere will be conducted under oxygen-deficient conditions. However, for the initial tests sufficient oxygen may be available to simulate repository conditions. The test vessel will be opened periodically for solution sampling and only a small fraction of the surface $(<1 \%)$ of the spent fuel will be expected to react. Later tests will have an independent source of oxygen and those results will be compared with those from the matrix I tests.

Also, some tests in matrix $\|$ will use fully oxidized spent fuel. Results from these tests will be compared to those from matrix I tests to help separate the effects of oxidation from those due to the effects of radiolysis products.

\subsubsection{Fuel Burnup}

A range of $M C C$-characterized spent fuel types will be tested. Initial tests with the two fuel types, ATM-103 and ATM-106, will determine the need for tests with spent fuels of higher or lower burnup. The effect of oxidized spent fuels will be assessed in later tests.

\subsubsection{Fuel Surface Area}

The tests will include spent fuel with minimum and maximum surface area; these tests will be part of matrix II. Tests with a minimum surface area will be those in which unfragmented fuel pellets are used. Tests with a maximum surface area will be those in which fragments are used. 


\subsubsection{Temperature}

Tests at two temperatures are planned. The majority of the tests will be done at $90^{\circ} \mathrm{C}$, a temperature which will probably be the lower temperature limit of the spent fuel after it has spent 1000 years in the repository. Accelerated tests will be done at $150^{\circ} \mathrm{C}$, to simulate extended times at the lower temperature.

\subsection{Sample Selection, Preparation, and Identification}

\subsubsection{Fuel and Cladding}

The spent fuel specimens will be ATM samples supplied by PNL-MCC. The core geometry, irradiation history, and characterization of the fuel specimens from two sources are given in references [15-16]. Any additional needed characterization will be done before use. The ATM-106 specimens are expected to exhibit a larger release of "gap" and grain boundary elements than ATM-103 samples.

The source of fragmented spent fuel segments will be those cut at MCC-PNL on June 1987 using the YMP-approved PNL procedure, Doc. No. SFL-2-1, Rev. 0 ("Preparation of Bare Fuel Specimens for NNWSI Spent Fuel Leaching/Dissolution Test") by C. N. Wilson (PNL). The ATM-103 was from rod MLA-098, segment M, Section 1; the ATM-106 was from rod NBD-107, segment $M$. The fuel from each section was individually packed under argon in $10.16 \mathrm{~cm}$ long, $1.905 \mathrm{~cm}$ O.D. stainless steel tubes capped with Swagelok fittings. Each, tube was identified with an MCC number, being 7 and 8, respectively.

The source of intact spent fuel pellets when used will be small rodlets that will be cut at MCC-PNL from rod locations falling within the plateau portions of ${ }^{137} \mathrm{Cs}$ gammascans and between axial locations of assembly grid spacers where localized bumup depressions occur. The ATM-103 will be from rod MLA-098, segment $X$; the ATM-106 will be from rod NBD-107, segment $N$. The fuel, in $15.24 \mathrm{~cm}$ sections, will be individually packed in stainless tubes and capped with Swagelok fittings under an argon atmosphere.

At Argonne, pellet slices will be cut from the ATM rodlets using DIW water. (A low-speed, water-lubricant Buehler saw with a low concentration diamond grit blade will be used.) The ends of the slices will be washed with methyl alcohol to remove fines. The outside of the cladding will be washed with acetone to remove particulate contamination.

\subsection{2 $\quad \underline{J}-13$ Water}

The water used in the tests will originate from well $\mathrm{J}-13$ located near Yucca Mountain, NV, whose cation and anion content approximates that of the repository pore fluid. This water will be equilibrated with Topopah Spring tuff at $90^{\circ} \mathrm{C}$ according to procedure NNWSI-05-009, and will be designated as EJ-13 water. The projected composition of EJ-13 water is shown in Table 3. This EJ-13 water may not have the oxygen fugacity and bicarbonate content of the pore fluid but should be considered the best approximation to the composition of the pore fluid. 


\subsubsection{Other Test Materials}

DIW to be used in the sample preparation and termination steps will have $>18$ megohm resistivity and will be analyzed for cations, anions, and carbon to determine its purity before initiation of the tests and periodically throughout the tests.

purchased.

Ultrex grade or similar grade nitric acid to be used for acid stripping will be

\subsection{Equipment Description}

\subsubsection{Test Vessel and Associated Equipment}

The test vessel and its matching cap will be constructed of $304 \mathrm{~L}$ stainless steel and will be sealed with a copper gasket. The vessels will be fabricated at ANL.

Acceptance criteria and production methods are given in document NNWSI-05-012. Copies of the engineering drawings are shown in Appendix $A$. The test vessel will contain the spent fuel and act to collect the test solutions. The vessel will not contact the spent fuel directly. One of the criteria for operations will be that the vessel be leaktight.

The water injection system will consist of a six-way valve and associated piping to introduce EJ-13 water into the appropriate test vessel in graduated amounts at the defined interval. This is an automated system that has been developed and pretested. The criteria for operations will be that the injection rates be controlled and produce drops that contact the spent fuel.

The pressure measurement system will consist of a standard tee with a pressure measurement device and a stainless steel sampling chamber attached. A mechanical, oil-less vacuum pump will be used to provide a low-level vacuum in the connecting lines.

Table 3. Composition of EJ-13 Water $(\mu \mathrm{g} / \mathrm{mL})$

\begin{tabular}{|l|c|l|c|}
\hline $\mathrm{pH}$ & 8.1 & $\mathrm{Sr}$ & 0.04 \\
\hline $\mathrm{Al}$ & 0.6 & $\mathrm{U}$ & 0.0 \\
\hline $\mathrm{B}$ & 0.2 & $\mathrm{~F}$ & 2.4 \\
\hline $\mathrm{Ca}$ & 9.1 & $\mathrm{Cl}$ & 7.2 \\
\hline $\mathrm{Fe}$ & 0.0 & $\mathrm{NO}_{3}^{-}$ & 7.6 \\
\hline $\mathrm{K}$ & $\mathrm{NA}$ & $\mathrm{NO}_{2}^{-}$ & $<0.5$ \\
\hline $\mathrm{Li}$ & 0.04 & $\mathrm{SO}_{4}{ }^{2-}$ & 17. \\
\hline $\mathrm{Mg}$ & 1.0 & $\mathrm{C} \mathrm{(org)}$ & 5.0 \\
\hline $\mathrm{Na}$ & 50 & $\mathrm{C}$ (inorg) & 26. \\
\hline $\mathrm{Si}$ & 45 & $\mathrm{HCO}_{3}^{\circ}$ & 135 \\
\hline
\end{tabular}




\subsubsection{Test Setup}

The configuration of the test vessel for the tests in Table 2 (except R6-1J1) is shown in Fig. 1. For R6-1 J1, a separate feed-through on the top of the test vessel will be added to have access for pressure measurement, gas sampling, and visual examination. All vessel components, except the copper gasket and the Zircaloy-4 test stand, will be made of 304L stainless steel. The vessels will be cleaned according to procedure NNWSI-05-010 before use. Before the start of the unsaturated tests, the vessels will undergo conditioning with deionized water. The injection system, shown in Fig. 2, will undergo conditioning with EJ-13 water. Lint-free gloves shall be used when handling the vessel components outside the hot cells. All reasonable precautions will be taken during the in-cell steps to prevent contamination of the samples and cross-contamination between tests.

All preparation and specimen assembly steps, as well as all component identification numbers, will be recorded in the Scientific Notebook.

\subsubsection{Test Operation}

The test vessel for each test in a matrix will be setup in the following sequential steps. The test will be initiated by adding EJ-13 water to the test vessel. The amount added will be $5 \mathrm{~mL}$ to vessels used for injection tests (X-1J1 and X-2J1) and $10 \mathrm{~mL}$ to vessels used for vapor tests $(X-V 1)$. The Zircaloy-4 stand containing the spent fuel will then be inserted into the vessel. The vessel will be sealed at $100 \mathrm{ft}-\mathrm{lb}$ torque. The unsaturated test procedure, NNWSI-05-011, will be used to time the injection of EJ-13 water into each vessel. The tests will be run in six-month periods, called a cycle, until the necessary information (e.g., approach to steady state) is obtained. The tests will be carried out in four cycles. (The length of the cycle is determined by the fluid capacity of the test vessel.)

Aliquots of the solutions will be taken at predetermined intervals to determine the rate and extent of radionuclide leaching under the conditions set by the initial test parameters. Aliquots will be taken monthly, at the end of each cycle, and at test termination. The monthly analyses will include a pH determination and examination by ICP-MS. Other analytical techniques (alpha spectrometry, etc.) will be used at the end of a cycle or at test termination. Sampling matrices are presented in Appendix B.

At the end of each cycle, the reaction vessel will be acid stripped. Duplicate test vessels will be started using the spent fuel from the prior cycle. The first cycle is intended to assess the magnitude of fission product release. In subsequent cycles test solution aliquots should exhibit steady actinide release rates.

Visual observations of the specimen surface will be made at each sampling period using an in-cell microscope and video system. All observations will be taped for record and future analysis. If feasible, the thickness of the alteration layer will be measured at the end of each cycle to provide an evolution history of layer growth. Microscopic, SEM/EDS, $X R D$, and TEM examination may be carried out after termination according to procedure NNWSI-05-021, depending on funding constraints. Particulate matter collected on filters will be subjected to microscopic examination. All archival analytical samples will be returned to the principal investigator. 


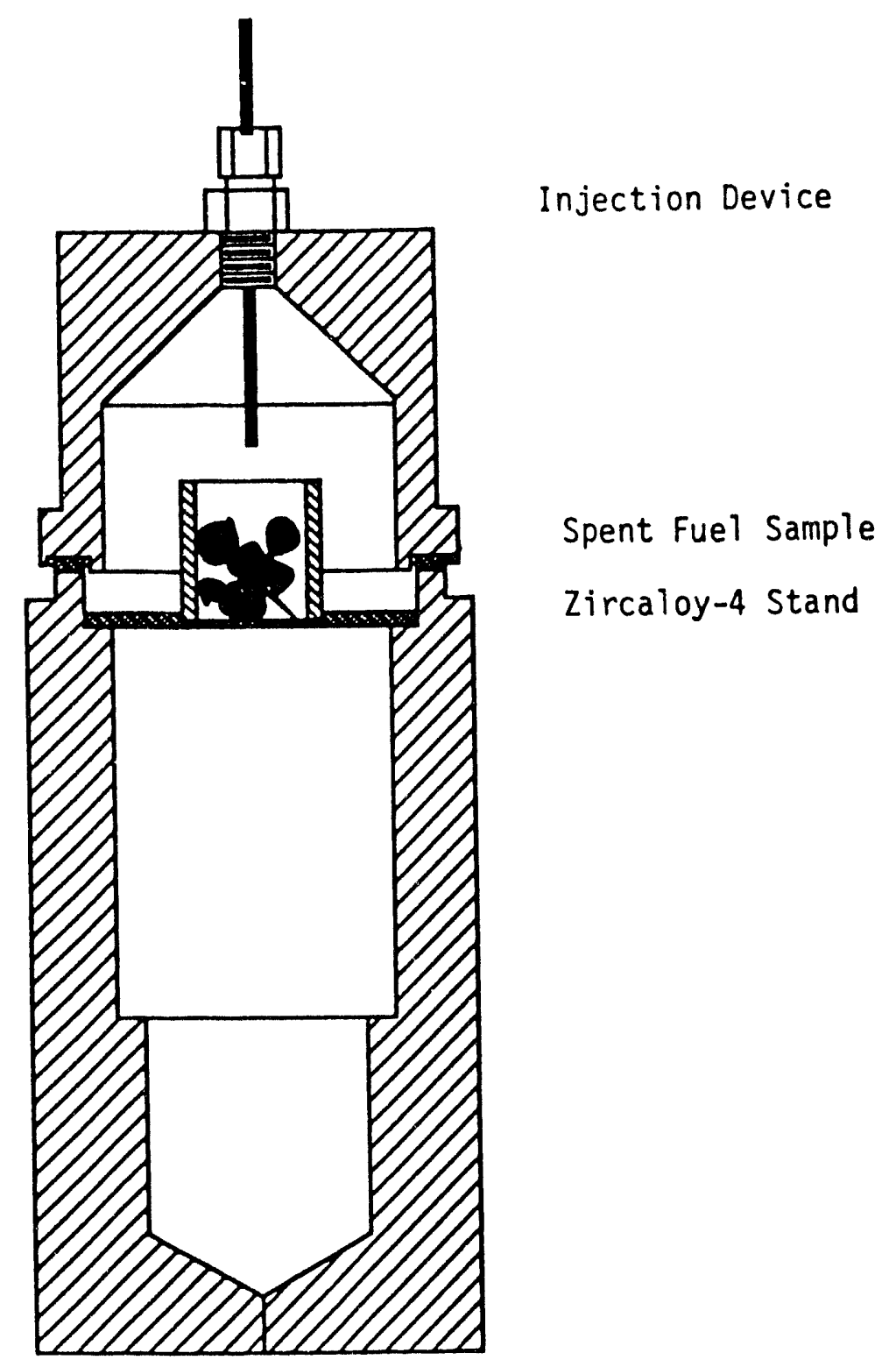

Figure 1. Test Vessel Configuration 


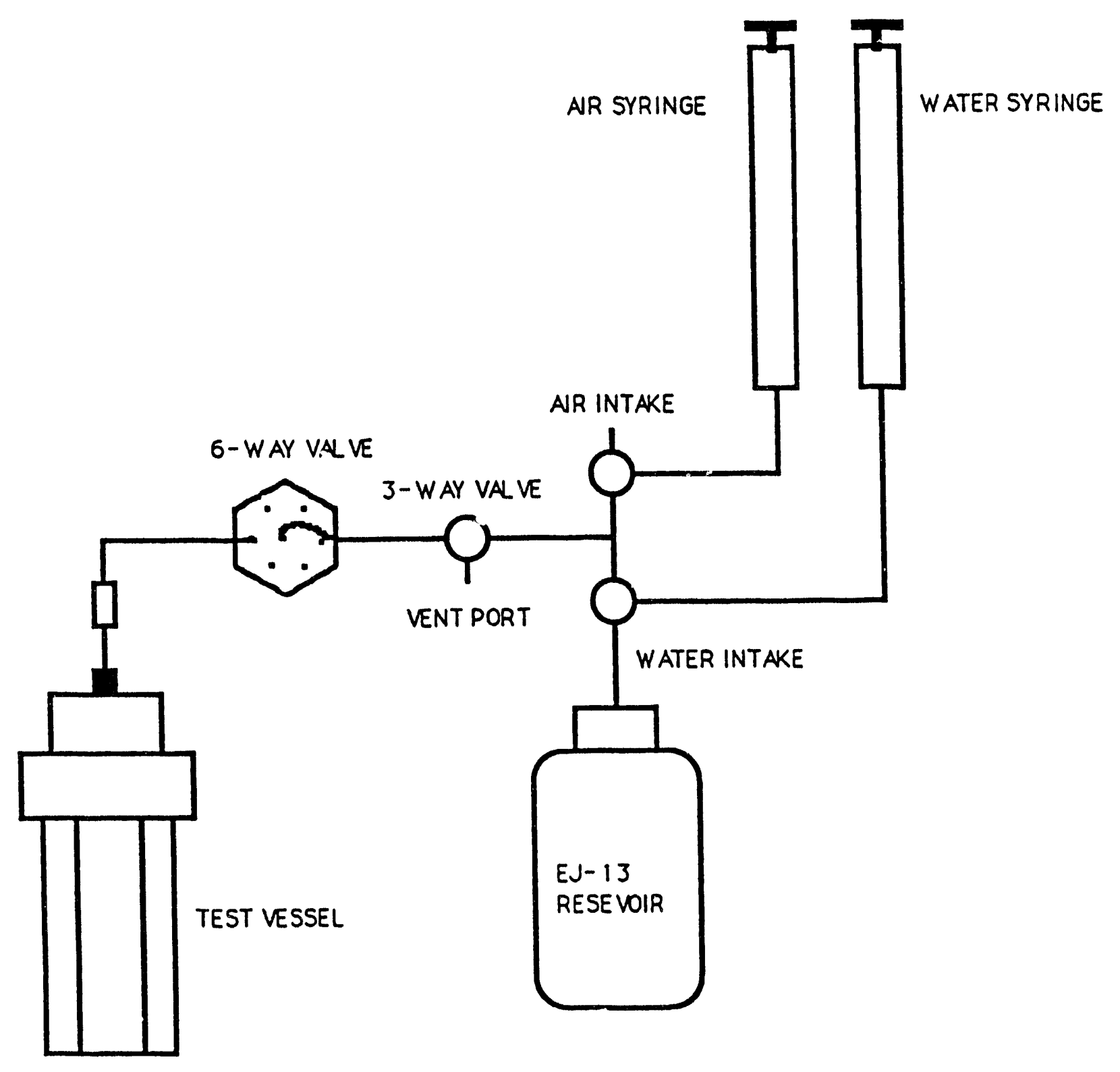

Figure 2. Test Injection System 


\section{$2.4 \quad$ Test Procedures}

The test procedures will be divided into three categories: (1) activities within the hot cells of Bldg. 205 and adjacent service area which are done to setup the tests, remove samples periodically, and terminate the test; (2) activities outside of the hot cell which are done to analyze the test solutions; and (3) activities inside and/or outside the hot cell which are done to characterize the alteration products. Procedures in the first category will include the following: test startup, periodic samples, $\mathrm{pH}$ measurement, total carbon analysis, sample weight determination, filter/fraction separation, speciation, sample acidification, and test termination. Procedures in the second category will include filter/fraction separation, analyses for radionuclides (Tc-99, Sr-90, Cs-137, C-14, 1-129, Se-79), analyses for actinides (U, Pu-239/240, Cm-244, Am-241, Np-237), total element analysis, speciation, anion analyses, and filter analyses. Elemental analyses will be done using ICP-MS. Speciation will be done using LPAS. Procedures in the third category will include sample preparation, analyses for elemental composition, analyses for compound identification, metallographic analyses.

The known existing procedures to be followed in this test will be these: NNWSI-05-009 (Equilibration of J-13 Water), NNWSI-05-010 (Cleaning Procedure for Test Vessels, Waste Form Holders, O-Rings and Polyethylene Containers Used in the NNWSI Unsaturated Test Method), NNWSI-05-011 (NNWSI Unsaturated Test Procedure), NNWSI-05-012 (Acceptance Specification and Production Method for Test Vessels, Waste Form Holders, and O-Rings Used in the NNWSI Unsaturated Test Method), and NNWSI-05-021 (Procedure for Qualitative Description of Test Components).

Standardization of the equipment used for the measurements will be according to Table 4. Any other M\&TE requirements will be reported in the Scientific Notebook.

\section{$2.5 \quad$ Analysis of Data}

Analytical data on solution composition will be compiled on a continually updated spreadsheet as noted in the Scientific Notebook. The results are expected to provide information on elementa! solution concentrations, total release of each element, rate of release of each element, amount of each element sorbed to the metal components, and species formed in solution. Sources of error will be evaluated and discussed in progress reports.

Raw analytical data will be reduced to (1) the total mass released from the fuel matrix for fission and actinide species, (2) the rate of individual radionuclide and actinide release, (3) elemental concentrations in solution, (4) water chemistry, (5) species form, and (6) species type (ion, colloid, etc.). Calculation methods will be recorded in the Scientific Notebook.

Analytical data on the solid alteration products will be recorded in the Scientific Notebook. Raw analytical data will include (1) the thickness of the alteration layer as a function of total time of reaction, (2) the elemental composition of the alteration layer, and (3) the compounds in the alteration layer. Correlations will be made between the secondary phases formed and the solution concentrations. 
Table 4. Required Measurements During Unsaturated Testing

\begin{tabular}{||l|l|l|l||}
\hline Measurement & $\begin{array}{l}\text { Applicable } \\
\text { Procedures } \\
\text { NNWSI-05-XXX }\end{array}$ & Device & $\begin{array}{l}\text { Frequency Check and } \\
\text { Methods }\end{array}$ \\
\hline \hline Temperature & 007,011 & Thermocouple & $\begin{array}{l}\text { Six months - secondary } \\
\text { thermometer vs. NIST } \\
\text { standard }\end{array}$ \\
\hline Length & $005,011,012$ & Micrometer & Standard foil, gauge blocks \\
\hline Mass & 008,004 & Balance & $\begin{array}{l}\text { Secondary standard. Six } \\
\text { months - NIST standard }\end{array}$ \\
\hline $\begin{array}{l}\text { Chemical } \\
\text { Concentration }\end{array}$ & $\begin{array}{l}003,011, \\
\text { YMP/G-05-036 }\end{array}$ & Analyt. Method & $\begin{array}{l}\text { NIST standard for each } \\
\text { procedure }\end{array}$ \\
\hline pH & M\&TE Sheet & pH Meter & $\begin{array}{l}\text { Commercial buffer solution } \\
\text { prior to measurement }\end{array}$ \\
\hline Volume & & Pipette & Weight measurements \\
\hline Water Inject. & 011 & Syringe & $\begin{array}{l}\text { Six months - mass of high } \\
\text { purity water transferred }\end{array}$ \\
\hline \hline
\end{tabular}

${ }^{a}$ All NNWSI-05-XXX procedures have been reissued in one volume as YMP-05-002.

${ }^{b} M \& T E$ Sheet $=$ calibration procedure attached to M\&TE sheet in QA files.

\subsection{Reporting and Data Recording}

Data received from ACL or ICP-MS determinations will be recorded in the working spreadsheet and cross-referenced in the Scientific Notebook. Cumulative data will be reported in monthly ANL reports. A topical report will be used for final compilation of data and results.

\subsection{RECORDS}

\subsection{Detailed Records}

Records generated during work in this Task will include the Task Plan, the Scientific Notebooks, data record sheets, ACL files and raw data, progress reports, and the final report. Technical review will be completed according to the QA Plan before documents will be filed for permanent record or distributed outside of ANL. 


\subsection{Identification}

Fuel rod segments and associated cladding delivered to ANL will be individually packed in closed stainless steel tubes. For fragmented samples, the fuel and cladding will be packed separately. Each tube will be identified in two ways: ANL Spec. No. and Rod Segment No. During the Period Start procedures, each tube will be assigned a corresponding Test No. according to Table 2. At that time, the Test No. will become the sole identification for the fuel and cladding specimens. All assignments will be recorded in the Scientific Notebook.

A total of eight vessels will be used for each set of tests. Vessel bottom portions and the corresponding caps will be stamped with consecutive numbers. In addition, test numbers will be indelibly marked on the corresponding vessels for additional identification. The test number includes information concerning the spent fuel type, S3 or S6, control, CC, and reference, R6; the type of injection, $1 \mathrm{~J}$ or $2 \mathrm{~J}$; vapor, $\mathrm{V}$; and the sequence of matrices, 1,2 , or 3. For example S6-1J1, a test from Table 2, uses ATM-106 fuel and an $0.075 \mathrm{~mL} 3.5 \mathrm{~d}$ injection rate, whereas R6-1J1, which also uses ATM-106 fuel and an $0.075 \mathrm{~mL} 3.5 \mathrm{~d}$ injection rate, would be pressure monitored.

Solution samples collected during periodic sampling and at termination will be identified by the following generic Sample ID Code: $X X-X X X-K-M T$, where $X X-X X X$ will be the test number, $K$ will be the cycle number, $M$ will be the number of elapsed days in the cycle, and $T$ will stand for the status of the termination samples. Here, $T=Q X$ will correspond to sequential aliquots of the final solution sample; $T=R$ will correspond to the rinse sample; and $\mathrm{T}=\mathrm{S}$ will correspond to the acid strip samples.

\subsection{QUAL.ITY ASSURANCE}

The tests will be performed in accordance with QA grading as assigned by the Functional Administrator and in concurrence with QA grading assigned for this activity D-20-43 as provided by LLNL. QA implementing procedures will be observed under the guidance of the generic QA Plan, YMP-02-001. The Principal Investigator is P. A. Finn, the Individual Scientists are J. C. Hoh and J. Emery, and the Functional Administrator is J. K. Bates. Other skilled personnel whose services are required in performing this Task will be identified in the Scientific Notebook.

\subsection{REFERENCES}

1. C. N. Wilson, Results from NNWSI Series 1 Spent Fuel Leach Test, Hanford Engineering Development Laboratory Report HEDL-TME 84-30 (1985).

2. C. N. Wilson, Results from Cycles 1 and 2 of NNWSI Series 2 Spent Fuel Dissolution Tests, Hanford Engineering Development Laboratory Report HEDL-TME 85-22 (1987). 
3. C. N. Wilson, Results from NNWSI Series 2 Bare Fuel Dissolution Tests, Pacific Northwest Laboratory Report PNL-7169 (1990).

4. C. N. Wilson, Results from NNWSI Series 3 Spent Fuel Dissolution Tests, Pacific Northwest Lboratory Report PNL-7170 (1990).

5. C. N. Wilson and C.J. Bruton, Studies on Spent Fuel Dissolution Behavior Under Proposed Yucca Mountain Repository Conditions, Lawrence Livermore National Laboratory Report UCRL-100223 (1989).

6. S. N. Nguyen, H. C. Weed, H. R. Leider, and R. B. Stout, Dissolution Kinetics of UO $2-$ Flow-through Tests on $\mathrm{UO}_{2.00}$ Pellets and Polycrystalline Schoepite Samples in Oxygenated, Carbonate/Bicarbonate Buffer Solutions at $25^{\circ} \mathrm{C}$, Lawrence Livermore National Laboratory UCRL-JC-107478 (1991).

7. C. N. Wilson and W. J. Gray, "The Effects of Water Composition on the Dissolution Rate of $\mathrm{UO}_{2}$ Under Oxidizing Conditions, paper presented at the 1st Annual International High-Level Radioactive Waste Management Conference, Las Vegas, April 1990.

8. W. J. Gray, H. Leider, and S. Steward, Parametric Study of LWR Spent Fuel Dissolution Kinetics, Lawrence Livermore National Laboratory Preprint UCRL-JC-110160 (1992).

9. J. K. Bates and T.J. Gerding, One-Year Results of the NNWSI Unsaturated Test Procedure: SRL 165 Glass Application, Argonne National Laboratory Report ANL-85-41 (1986).

10. D. J. Wronkiewicz, J. K. Bates, T. J. Gerding, E. Veleckis, and B. S. Tani, Leaching Action of $E J-13$ Water on Unirradiated $\mathrm{UO}_{2}$ Surfaces Under Unsaturated Conditions at 90 $\mathrm{C}$ : Interim Report, Argonne National Laboratory Report ANL-91/11 (1991).

11. Siting of Fuel Reprocessing Plants and Waste Management Facilities, Oak Ridge National Laboratory Report ORNL-4451 (1971).

12. I. G. Draganic and Z. D. Draganic, The Radiation Chemistry of Water, Academic Press, New York (1971).

13. P. Cohen, Water Coolant Technology of Power Reactors, Gordon and Breach Scientific Publishers, New York (1969).

14. A. O. Allen, "Radiation Chemistry of Aqueous Solutions," J. Phys. Coll. Chem. 52, 479 (1948).

15. R. J. Guenther et.al, Characterization of Spent Fuel Approved Testing Material ATM-103, Pacific Northwest Laboratory PNL-5109-103 (1988).

16. R. J. Guenther et.al, Characterization of Spent Fuel Approved Testing Material ATM-106, Pacific Northwest Laboratory PNL-5109-106 (1988). 
17. J. K. Bates and T. J. Gerding NNWSI Phase II Materials Interactions Test Procedure and Preliminary Results, Argonne National Laboratory ANL-84-81 (1984).

18. C. E. Johnson et al. Nuclear Technology Programs Semiannual Progress Report, October 1985-March 1987, Argonne National Laboratory Report ANL-88-28 (1988).

19. J. K. Bates, T. J. Gerding, T. A. Abrajano, and W. L. Ebert NNWSI Waste Form Testing at Argonne National Laboratory, Semiannual Report, July-December 1985, Lawrence Livermore National Laboratory Report UCRL-15801 (1986).

20. J. K. Bates, T. J. Gerding, and E. Veleckis, "Repository Relevant Testing Applied to the Yucca Mountain Project," presented at the Amer. Chem. Soc. Mtg., Dallas, TX, April 9-14, 1989.

21. J. K. Bates, D. F. Fischer, and T. J. Gerding The Reaction of Glass During Gamma Irradiation in a Saturated Tuff Environment. Part 1: SRL 165 Glass, Argonne National Laboratory Report ANL-85-62 (1986). 
APPENDIX A - SKETCHES 
A.1. Test Vessel

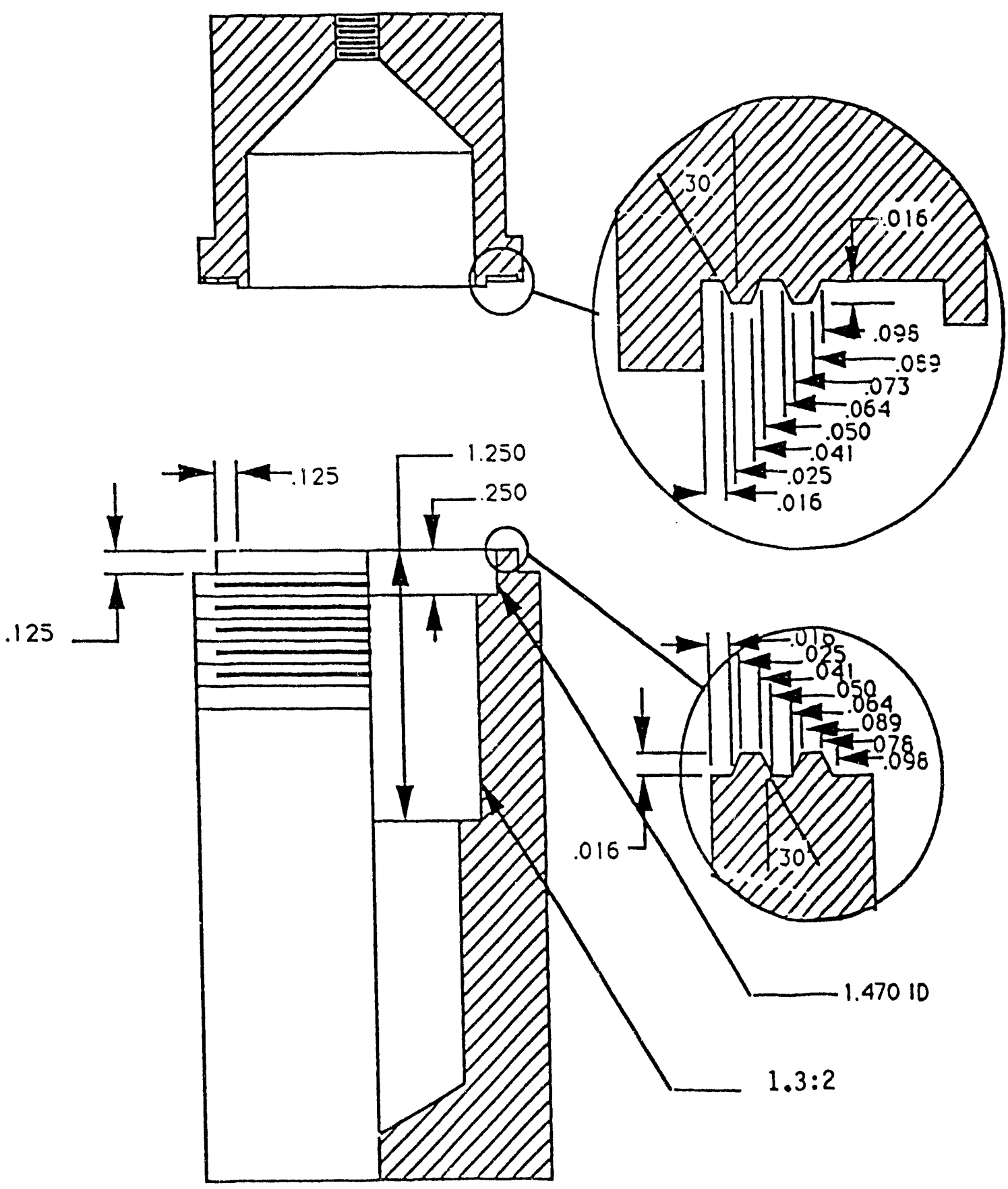


A.2. Sample Holder
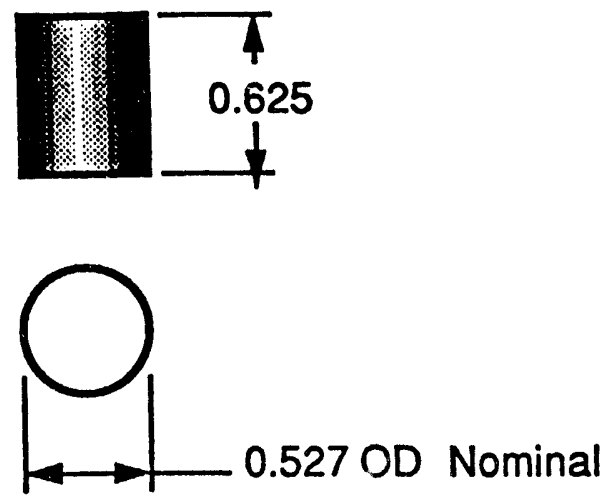

Zirc-4 Tubing

NOTE: Tubing to have square ends and no burrs.
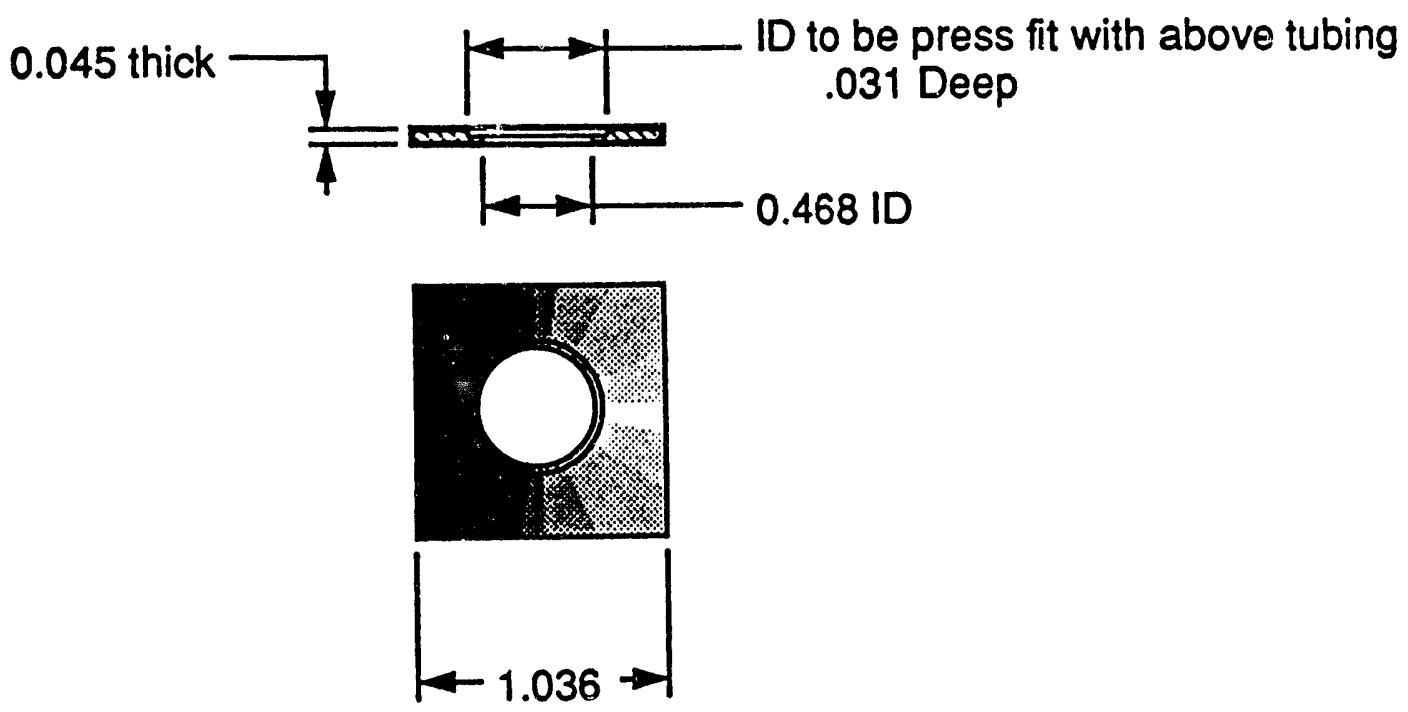

square 


\section{APPENDIX B - MATRICES FOR SOLUTION SAMPLES FOR SPENT FUEL UNSATURATED TESTS}

Two matrices for solution samples are shown, Table B.1 and Table B.2. The former matrix is used for the vapor tests, the control test, and the tests using a $0.075 \mathrm{~mL} / 3.5 \mathrm{~d}$ injection rate. The latter matrix is used for tests with a $0.75 \mathrm{~mL} / 3.5 \mathrm{~d}$ injection rate.

The matrices show sample aliquots taken each 28-30 days, which is an optional schedule. The total solution in each test vessel will be removed at the end of each six-month period, i.e., at the end of each cycle of $\sim 168$ days. The vessel will then be acid-stripped and appropriate aliquots taken to account for all leached material.

Changes may be made to the sampling and cycle matrices depending on the results of analyses. Such changes will be documented in the Scientific Notebook and in reports.

Table B.1. Sample Matrix for Vapor and Low Injection Rate Tests

\begin{tabular}{|c|c|c|c|c|c|c|c|c|}
\hline $\begin{array}{l}\text { Time } \\
\text { (d) }\end{array}$ & $\begin{array}{l}\text { Vol. } \\
(\mathrm{mL})\end{array}$ & $\begin{array}{c}\text { Type } \\
\text { Sample }\end{array}$ & ID & $\mathrm{pH}$ & $\begin{array}{c}\text { Filter } \\
400 \mathrm{~nm}\end{array}$ & a & b & C \\
\hline$\overline{23}$ & 0.2 & $\overline{\sin }$ & S3-1J1-1-28 & $\bar{Y}$ & $\bar{N}$ & $\bar{Y}$ & $\bar{Y}$ & $\mathrm{~N}$ \\
\hline 56 & 0.2 & $\sin$ & S3-1J1-1-56 & $\bar{Y}$ & $N$ & Y & $Y$ & $\mathrm{~N}$ \\
\hline 84 & 0.2 & SIn & S3-1J1-1-84 & $\bar{Y}$ & $\mathrm{~N}$ & $\mathbf{Y}$ & $Y$ & $\mathbf{N}$ \\
\hline$\pi \sqrt{2}$ & 0.2 & $\sin$ & S3-1J1-1-112 & Y & $\mathrm{N}$ & $\mathbf{Y}$ & $\mathbf{Y}$ & $N$ \\
\hline 140 & 0.2 & SIn & S3-1J1-1-140 & $\bar{Y}$ & $\mathrm{~N}$ & $\mathrm{Y}$ & $Y$ & $\mathrm{~T}$ \\
\hline 168 & $0.2-1$ & $\sin$ & S3-1J1-1-168Q1 & Y & $\mathrm{N}$ & $\mathbf{Y}$ & $Y$ & $\mathbf{N}$ \\
\hline 168 & $0.2-1$ & $\operatorname{Sin}$ & S3-1J1-1-168Q2 & $\mathrm{N}$ & $\mathbf{Y}$ & $\mathrm{Y}$ & 7 & $\mathbf{N}$ \\
\hline 168 & $0.2-1$ & STn & S3-1J1-1-168Q3 & $N$ & $\mathbb{N}$ & $\mathbf{Y}$ & 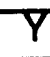 & $\bar{Y}$ \\
\hline 168 & $0.2-1$ & SIn & S3-1J1-1-168Q4 & $\mathbb{N}$ & $\mathbf{P}$ & $\mathrm{Y}$ & Y & $\mathbf{Y}$ \\
\hline 168 & $0.2-1$ & $\sin$ & S3-1J1-1-168S & Y & $\mathbf{Y}$ & $\mathbf{Y}$ & $\mathrm{P}$ & $Y$ \\
\hline 168 & $0.2-1$ & $\sin$ & S3-1J1-1-168R & Y & Y & $\mathrm{Y}$ & $Y$ & $\bar{Y}$ \\
\hline
\end{tabular}

Actinides: U, Pu, Am, Np, $\mathrm{Cm}$ as shown by ICP-MS.

badionuclides: Tc, Cs, Sr, Se, I, C.

'Other: speciation, colloids. 
Table B.2. Sample Matrix for a High Injection Rate Test

\begin{tabular}{|c|c|c|c|c|c|c|c|c|}
\hline $\begin{array}{l}\text { Time } \\
\text { (d) }\end{array}$ & $\begin{array}{l}\text { Vol. } \\
(\mathrm{mL})\end{array}$ & $\begin{array}{l}\text { Type } \\
\text { Sample }\end{array}$ & ID & $\mathrm{pH}$ & $\begin{array}{c}\text { Filter } \\
400 \mathrm{~nm}\end{array}$ & a & b & c \\
\hline$\overline{28}$ & 2.0 & $\overline{S T n}$ & |S3-2J1-1-28 & $\bar{Y}$ & $\mathrm{~N}$ & $\bar{Y}$ & $\mathrm{Y}$ & $\mathrm{N}$ \\
\hline 56 & 2.0 & SIn & S3-2J1-1-56 & P & $\mathrm{N}$ & $\mathbf{Y}$ & $\mathrm{Y}$ & $N$ \\
\hline 84 & 2.0 & SIn & S3-2JT-1-84 & Y & $\mathrm{N}$ & $\mathrm{Y}$ & $\mathrm{Y}$ & $\mathbf{N}$ \\
\hline 112 & 2.0 & $\sin$ & S3-2J1-1-1T2 & Y & $\mathrm{N}$ & $\mathrm{Y}$ & $\mathrm{Y}$ & $\mathrm{N}$ \\
\hline 140 & 2.0 & $\sin$ & S3-2J1-1-140 & Y & $\mathrm{N}$ & $\mathrm{P}$ & $\mathrm{Y}$ & $\mathbb{N}$ \\
\hline 168 & 2.0 & SIn & |S3-2J1-1-168Q1 & Y & $\mathrm{N}$ & $\mathrm{Y}$ & $\mathrm{P}$ & $N$ \\
\hline 168 & 2.0 & SIn & S3-2JT-1-168Q2 & $\mathrm{N}$ & $\mathrm{Y}$ & $\mathrm{Y}$ & $\mathrm{P}$ & $N$ \\
\hline 168 & 2.0 & Sin & S3-2J1-1-168Q3 & $\mathrm{N}$ & $\mathrm{N}$ & $\mathrm{Y}$ & $\mathrm{Y}$ & $\mathbf{Y}$ \\
\hline 168 & 2.0 & SIn & S3-2J1-1-168Q4 & $\mathbb{N}$ & P & $\mathrm{Y}$ & $\mathrm{Y}$ & $\mathbf{Y}$ \\
\hline 168 & 2.0 & Sin & |S3-2JT-1-168S & $\mathrm{Y}$ & $\mathrm{Y}$ & $\mathrm{Y}$ & $\mathrm{P}$ & $\mathbf{Y}$ \\
\hline 768 & 2.0 & SIn & S3-2J1-1-168R & $\mathrm{Y}$ & $\mathrm{Y}$ & $\mathrm{Y}$ & $\mathrm{Y}$ & $\mathbf{Y}$ \\
\hline
\end{tabular}

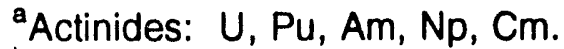

badionuclides: Tc, Cs, Sr, Se, I, C.

'Other: speciation, colloids. 


\title{
APPENDIX C
}

\author{
ARGONNE NATIONAL LABORATORY \\ Chemical Technology Division \\ 9700 South Cass Avenue \\ Argonne, Illinois 60439-4837
}

\section{UNSATURATED SPENT FUEL PROGRAM}

\section{TEST PLAN \\ Surface Reactions between EJ-13 Water and $\mathrm{UO}_{2}$ Pellets under Unsaturated Conditions at $90^{\circ} \mathrm{C}$}

Document No. YMP/SF-3A-009

Original Issue: 09/21/92

Prepared by:

Principal Investigator

Date

Reviewed by:

Individual Scientist

Date

Reviewed by:

Quality Assurance Coordinator

Date

Approved by:

Functional Administrator

Date 


\section{TEST PLAN: SURFACE REACTIONS BETWEEN EJ-13 WATER AND UO 2 PELLETS UNDER UNSATURATED CONDITIONS AT $90^{\circ} \mathrm{C}$}

\subsection{INTRODUCTION}

This subtask is performed under the guidance of the Yucca Mountain Project (YMP) and is part of activity D-20-43 as indicated in the YMP/LLNL Spent Fuel Scientific Investigation Plan. The Principal Investigator is D. J. Wronkiewicz, the Individual Scientist is T. J. Gerding, and the Functional Administrator is J. K. Bates

\subsection{OBJECTIVE}

The objective of this subtask is to reevaluate the Unsaturated Test Method (drip test) in measuring the reactivity of $\mathrm{UO}_{2}$ under potential repository conditions. The drip test is being used to study $\mathrm{UO}_{2}$ reaction in an ongoing set of parametric experiments [10] (Series PMP8U). In these tests a large pulse of uranium release was observed, and a complex array of secondary uranyl phases were identified. The tests were conducted with the $\mathrm{UO}_{2}$ assembly supported by a Teflon stand. At the conclusion of these tests, a fluoropolymer phase was identified on the top surface of the $\mathrm{UO}_{2}$ pellets. The current set of tests will be done with no Teflon present in the test vessel. Comparison of the present test results with those of the Teflon-supported tests will be used to evaluate what influence, if any, the Teflon stands have had on the $\mathrm{UO}_{2}$ reaction. The time-dependent reactivity of the $\mathrm{UO}_{2}$ in these tests will be measured by solution composition and secondary phase formation.

\section{$1.2 \quad$ BACKGROUND}

Unsaturated experiments to study the reactions of $\mathrm{EJ}-13$ water with unirradiated $\mathrm{UO}_{2}$ surfaces have been underway at ANL for several years $[9,10,17-20]$.

Some of the unexpected findings in this study were the pulse of $U$ release between $\sim 1$ to 2 years of reaction and the irregular behavior of Teflon support stands. The increased $U$ release period was accompanied by the formation of a variety of secondary uranyl phases and a multitude of feather-like white phases near the outer perimeter of $\mathrm{UO}_{2}$ specimen surface. These latter crystals were identified as a fluoropolymer from XRD patterns and FTIR spectra. The process responsible for fluoropolymer formation is not clear. It is possible that in the humid atmosphere of a closed vessel at $90^{\circ} \mathrm{C}$, the radioactivity from $\mathrm{UO}_{2}$ could have broken polymer chains in Teflon to a length where the fluoropolymer could sublime and then redeposit on the specimen.

The occurrence of the increased reactivity of the $\mathrm{UO}_{2}$ pellets may have repercussions in evaluating the performance of the high-level waste (HLW) repository, if the $\mathrm{UO}_{2}$ pellets react in a manner similar to that of spent fuel. Therefore, it is of interest to determine whether the increased $U$ release can be reproduced in the absence of Teflon, and to observe whether contact between $\mathrm{UO}_{2}$ and thin films, i.e., conditions with high surface area-to-volume ratios, of 
water results in reaction processes different than that observed under saturated conditions, i.e., those with a low surface area-to-volume ratio.

\subsection{TEST DESCRIPTION}

Teflon may have interfered with the $\mathrm{UO}_{2}$ reaction processes either by physically blocking potential reaction sites or by participating in the chemical reactions themselves. To assess the effects of Teflon on the $\mathrm{UO}_{2}$ reaction in the foregoing Unsaturated Tests, it is necessary to perform a control test in which all Teflon is eliminated from the reaction vessel.

The configuration of $\mathrm{UO}_{2}$ in the tests will be three $\mathrm{UO}_{2}$ pellets stacked inside a Zircaloy-4 tube. The Zircaloy- $4 / \mathrm{UO}_{2}$ assemblage will rest on a $304 \mathrm{~L}$ stainless steel support stand instead of Teflon. The test will be performed in quadruplicate and will be assigned numbers PMP8U-9, PMP8U-10, PMP8U-11, and PMP8U-12. As a control, two new tests, PMP8U-13 and PMP8U-14, will be done with Teflon stands. These tests will be exact repeats of tests PMP8U-5 and PMP8U-6 done previously [10].

\subsection{TEST MATRIX}

The test matrix will be identical to that used in reference 10 as described in procedure NNWSI-05-011 (Rev. 02), p. 11, with the following exceptions: periodic changes will be made at intervals of 13 weeks instead of 6.5 weeks, and the test will be performed in quadruplicate. Any other changes in the matrix made during the test will be documented in the Scientific Notebook.

\subsection{SAMPLE SELECTION, PREPARATION, AND IDENTIFICATION}

Each sample will consist of a stack of three $\mathrm{UO}_{2}$ pellets with a natural isotopic composition. The pellets will be obtained from the vaults of ANL (SPM Batch No. 4-4-110). They will be mounted in a Zircaloy-4 tube with the smooth as-pressed surfaces facing outwards. Zircaloy-4 tubing will be obtained from the ANL stockroom without a batch specification number. The water to be used in the test will originate from well $\mathrm{J}-13$ located near Yucca Mountain, NV. This water will be equilibrated with Topopah Spring tuff according to a procedure described in reference 21 and will be referred to as the EJ-13 water. All specimen assembly steps, as well as all component identification numbers, will be reported in the Scientific Notebook.

\subsection{EQUIPMENT DESCRIPTION}

All equipment to be used in the test will be identical to that used in the previous Unsaturated Tests (for references see Section 1.2), with the exception of a Teflon stand. Acceptance specifications and production methods are given in document NNWSI-05-012. The main portion of the apparatus will consist of a $304 \mathrm{~L}$ stainless steel vessel containing the 
specimen-Zircaloy assembly that will rest on a $304 \mathrm{~L}$ stainless steel stand. The vessel will be sealed with a matching cap.

\subsection{TEST OPERATION}

The procedure to be followed in the test is identified in Document NNWSI-05-001 (Rev. 02) but applied specifically to $\mathrm{UO}_{2}$. Any deviations from the procedure will be described in the Scientific Notebook. The test will be performed at $90^{\circ} \mathrm{C}$ on a three-pellet $\mathrm{UO}_{2}$ specimen that is encased in Zircaloy cladding placed on a stainless steel stand and sealed in an air-tight stainless steel vessel. Accurately measured quantities of EJ-13 water will be dripped on the specimen from an injection system at a rate of $0.075 \mathrm{~mL}$ every 3.5 days. The test will be interrupted for solution sampling and $\mathrm{UO}_{2}$ inspection at intervals specified in Section 2.1. The total length of the test will be determined on the basis of the results.

Standardization of the equipment required for the measurements during the test will be made according to Table 1. Any other M\&TE requirements will be reported in the Scientific Notebook.

\subsection{POST-TEST SOLUTION/SAMPLE EVALUATION}

Visual observations of the specimen surface will be made at each sampling period. Microscopic, SEM/EDS, XRD, and TEM examinations may be carried out after termination according to procedure NNWSI-05-021. All archival analytical samples will be retumed to the PI.

\subsection{ANALYSIS OF DATA}

Raw analytical data will be reduced to (1) the total mass released from the specimen for uranium and (2) the concentrations in solutions for the anions and cations. Calculation methods will be recorded in the Scientific Notebook. A correlation will be made between those secondary phases formed and the solution concentrations.

\subsection{PROCEDURE}

Written procedures used in this Task are identified in Sections 2.1, 2.3, 2.4, and 2.5. In addition, solution analyses carried out by the Analytical Chemistry Laboratory will follow procedures NNWSI-RNL-05-016 for the anions, NNWSI-05-003 for the cations, and YMP/G-05-036 for uranium.

\subsection{REPORTING AND DATA RECORDING}

The data will be reported in monthly reports to LLNL, and records turnover will follow YMP requirements. A topical report will be used for final compilation of data and results. 
Table 1. Required Measurements Made During Unsaturated Testing

\begin{tabular}{||l|l|l|l||}
\hline Measurement & $\begin{array}{l}\text { Applicable } \\
\text { Procedures } \\
\text { NNWSI-05-XXX }\end{array}$ & Device & $\begin{array}{l}\text { Frequency Check and } \\
\text { Methods }\end{array}$ \\
\hline \hline Temperature & 007,011 & Thermocouple & $\begin{array}{l}\text { Six months - secondary } \\
\text { thermometer vs. NIST } \\
\text { standard }\end{array}$ \\
\hline Length & $005,011,012$ & Micrometer & Standard foil, gauge blocks \\
\hline Mass & 008,004 & Balance & $\begin{array}{l}\text { Secondary standard. Six } \\
\text { months - NIST standard }\end{array}$ \\
\hline $\begin{array}{l}\text { Chemical } \\
\text { Concentration }\end{array}$ & $\begin{array}{l}003,011, \\
\text { YMP/G-05-036 }\end{array}$ & Analyt. Method & $\begin{array}{l}\text { NIST standard for each } \\
\text { procedure }\end{array}$ \\
\hline pH & M\&TE Sheet & pH Meter & $\begin{array}{l}\text { Commercial buffer solution } \\
\text { prior to measurement }\end{array}$ \\
\hline Volume & Pipette & Weight measurements \\
\hline Water Inject. & 011 & Syringe & $\begin{array}{l}\text { Six months - mass of high } \\
\text { purity water transferred }\end{array}$ \\
\hline
\end{tabular}

${ }^{a} \mathrm{All} N \mathrm{NWSI}-05-\mathrm{XXX}$ procedures have been reissued in one volume as YMP-05-002.

${ }^{b}$ Measurements do not affect quality of data.

${ }^{c}$ M\&TE Sheet = calibration procedure attached to M\&TE sheet in QA files.

\subsection{RECORDS}

\section{$3.1 \quad$ DETAILED RECORDS}

1. This document.

2. Technical reports, including a final report.

3. Analytical reports.

4. Scientific Notebooks. 
Distribution for ANL-92/48

Internal:
A. Anderson
J. E. Helt
J. K. Bates (25)
M. J. Steindler
J. E. Battles
J. C. Cunnane
ANL Patent Dept.
J. E. Harmon
TIS Files

\section{External:}

DOE-OSTI (2)

ANL-E Library (2)

ANL-W Library

Manager, Chicago Field Office, DOE

A. Bindokas, DOE-CH

J. C. Haugen, DOE-CH

Chemical Technology Division Review Committee Members:

S. Baron, Brookhaven National Laboratory, Upton, NY

D. L. Douglas, Consultant, Bloomington, MN

N. Jarrett, Noel Jarrett Associates, Lower Burrell, PA

J. G. Kay, Drexel University, Philadelphia, PA

J. Stringer, Electric Power Research Institute, Palo Alto, CA

J. B. Wagner, Arizona State University, Tempe, AZ

R. G. Wymer, Consultant, Oak Ridge, TN

T. Ahn, U. S. Nuclear Regulatory Commission, Washington, DC

C. R. Allen, Nuclear Waste Technical Review Board, Pasadena, CA

J. Allison, USDOE, Office of Waste Operations, Germantown, MD

E. Anderson, Mountain West Research-Southwest, Inc., Phoenix, AZ

D. H. Appel, U.S. Geological Survey, Denver, CO

M. J. Apted, Interra Sciences, Denver, CO

D. J. Bales, USDOE, Scientific and Technical Information, Oak Ridge, TN

L. Ballou, Lawrence Livermore National Laboratory, Livermore, CA

L. H. Barrett, USDOE, Storage and Transportation, Washington, DC

J. W. Bartlett, USDOE, Civilian Radioactive Waste Management, Washington, DC

M. L. Baughman, Fiskdale, MA

D. A. Beck, U.S. Geological Survey, Las Vegas, NV

C. G. Bell, Jr., University of Nevada, Las Vegas, NV

A. Berusch, USDOE, Civilian Radioactive Waste Management, Washington, DC

N. E. Bibler, Westinghouse Savannah River Co., Aiken, SC

E. P. Binnall, Lawrence Berkeley Laboratory, Berkeley, CA

M. Blanchard, DOE Field Office, Las Vegas, NV

T. E. Blejwas, Sandia National Laboratories, Albuquerque, NM (5)

J. Blink, Lawrence Livermore National Laboratory, Las Vegas, NV

W. Bourcier, Lawrence Livermore National Laboratory, Livermore, CA 
S. Bradhurst, Reno, NV

J. C. Bresee, USDOE, Civilian Radioactive Waste Management, Washington, DC

S. J. Brocoum, USDOE, Civilian Radioactive Waste Management, Washington, DC

C. Bruton, Lawrence Livermore National Laboratory, Livermore, CA

R. L. Bullock, Raytheon Services Nevada, Las Vegas, NV

J. C. Calovini, Holmes \& Narver, Inc., Las Vegas, NV

D. Campbell, U.S. Bureau of Reclamation, Denver, $\mathrm{CO}$

J. E. Cantlon, Nuclear Waste Technical Review Board, East Lansing, MI

M. W. Carter, Nuclear Waste Technical Review Board, Atlanta, GA

K. W. Causseaux, U.S. Geological Survey, Denver, CO

Center for Nuclear Waste Regulatory Analyses, San Antonio, TX

K. A. Chacey, USDOE, Office of Waste Management, Germantown, MD

D. Chesnut, Lawrence Livermore National Laboratory, Livermore, CA

P. Childress, Lynchburg, VA

City Manager, City of Henderson, Henderson, NV

W. L. Clarke, Lawrence Livermore National Laboratory, Livermore, CA

P. Cloke, Science Applications International Corp., Las Vegas, NV

M. O. Cloninger, Yucca Mountain Project Office, Las Vegas, NV

B. W. Colston, Raytheon Services Nevada, Las Vegas, NV

Community Planning and Development, North Las Vegas, NV

C. F. Costa, U.S. Environmental Protection Agency, Las Vegas, NV

R. W. Craig, U.S. Geological Survey, Las Vegas, NV

D. U. Deere, Nuclear Waste Technical Review Board, Arlington, VA

Department of Comprehensive Planning, Clark County, Las Vegas, NV

Director of Community Planning, Boulder City, NV

J. F. Divine, U. S. Geological Survey, Reston, VA

M. J. Dorsey, Reynolds Electric \& Engineering Co., Inc., Las Vegas, NV (2)

R. S. Dyer, Yucca Mountain Project Office, Las Vegas, NV

Economic Development Department, Las Vegas, NV

R. Einziger, Pacific Northwest Laboratories, Richland, WA

D. R. Elle, USDOE, DOE Field Office, Las Vegas, NV

R. Erickson, USDOE, Office of Waste Operations, Germantown, MD

P. Eslinger, Pacific Northwest Laboratories, Richland, WA

R. C. Ewing, University of New Mexico, Albuquerque, NM

C. E. Ezra, EG\&G Energy Measurements, Inc., Las Vegas, NV

L. J. Fiorenzi, Eureka, NV

R. Fish, B\&W Fuel Co., Las Vegas, NV

P. K. Fitzsimmons, USDOE, DOE Field Office, Las Vegas, NV

A. L. Flint, U.S. Geological Survey, Mercury, NV

J. Fordham, Desert Research Institute, Reno, NV

J. Foremaster, City of Caliente, Caliente, NV (5)

L. D. Foust, Valley Bank Center, Las Vegas, NV (2)

D. L. Fraser, Reynolds Electrical \& Engineering Co., Inc., Las Vegas, NV

C. P. Gertz, USDOE, Office of Geologic Disposal, Washington, DC

C. P. Gertz, USDOE, DOE Field Office, Las Vegas, NV (5)

P. A. Glancy, U.S. Geological Survey, Carson City, NV 
V. M. Glanzman, U.S. Geological Survey, Denver, CO

A. E. Gurrola, Holmes \& Narver, Inc., Las Vegas, NV

J. Hale, USDOE, Civilian Radioactive Waste Management, Washington, DC

D. Harrison, Yucca Mountain Project Office, Las Vegas, NV

T. Hay, Office of the Governor, State of Nevada, Carson City, NV

L. R. Hayes, U. S. Geological Survey, Denver, CO (6)

D. Hedges, Roy F. Weston, Inc., Las Vegas, NV

E. J. Helley, U.S. Geological Survey, Menlo Park, CA

R. J. Herbst, Los Alamos National Laboratory, Los Alamos, NM (4)

W. M. Hewitt, Roy F. Weston, Inc., Washington, DC

D. G. Horton, USDOE, Office of Quality Assurance, Washington, DC

T. O. Hunter, Sandia National Laboratories, Albuquerque, NM

C. Interrante, U.S. Nuclear Regulatory Commission, Washington, DC

T. H. Isaacs, USDOE, Strategic Planning \& International Programs, Washington, DC

R. E. Jackson, Roy F. Weston, Inc., Washington, DC

C. Jantzen, Westinghouse Savannah River Co., Aiken, SC

L. J. Jardine, Lawrence Livermore National Laboratory, Livermore, CA (3)

C. H. Johnson, State of Nevada, Carson City, NV

H. N. Kalia, Los Alamos National Laboratory, Las Vegas, NV

W. R. Keefer, U.S. Geological Survey, Denver, CO

W. S. Ketola, USDOE, West Valley Project Office, West Valley, NY

B. G. Kitchen, Savannah River Laboratory, Aiken, SC

K. Knauss, Lawrence Livermore National Laboratory, Livermore, CA

D. A. Knecht, Westinghouse Idaho Nuclear Co., Idaho Falls, ID

M. Kreiter, Pacific Northwest Laboratory, Richland, WA

D. Langmuir, Nuclear Waste Technical Review Board, Golden, CO

W. Lee, University of California, Berkeley, CA

H. Leider, Lawrence Livermore National Laboratory, Livermore, CA

W. Lin, Lawrence Livermore National Laboratory, Livermore, CA

Lincoln County Commission, Lincoln County, Pioche, NV

D. L. Lockwood, Fenix \& Scisson of Nevada, Las Vegas, NV

R. R. Loux, Jr., State of Nevada, Carson City, NV (3)

R. E. Lowder, MAC Technical Services, Valley Bank Center, Las Vegas, NV

R. W. Lynch, Sandia National Laboratories, Albuquerque, NM

S. Marschman, Pacific Northwest Laboratory, Richland, WA

W. McKenzie, Lawrence Livermore National Laboratory, Livermore, CA

G. B. Mellinger, Battelle Pacific Northwest Laboratory, Richland, WA

B. Mettam, Goldfield, NV

M. Mifflin, Desert Research Institute, Las Vegas, NV

R. A. Milner, USDOE, Storage and Transportation, Washington, DC

R. Morissette, Science Applications International Corp., Las Vegas, NV

P. K. Nair, Center for Nuclear Waste Regulatory Analyses, San Antonio, TX

J. H. Nelson, Science Applications International Corp., Las Vegas, NV

S. Nguyen, Lawrence Livermore National Laboratory, Livermore, CA

P. Niedzeilski-Eichner, Fairfax, VA

D. W. North, Nuclear Waste Technical Review Board, Los Altos, CA 
NRC Document Control Desk, Division of Waste Management, Washington, DC Nuclear Waste Management Library, Lawrence Livermore Natl. Lab., Livermore, CA

W. O'Connell, Lawrence Livermore National Laboratory, Livermore, CA ONWI Library, Battelle Columbus Laboratory, Columbus, $\mathrm{OH}$

V. M. Oversby, Lawrence Livermore National Laboratory, Livermore, CA

G. J. Parker, USDOE, Civilian Radioactive Waste Management, Washington, DC

F. G. Peters, USDOE, Civilian Radioactive Waste Management, Washington, DC

F. G. Peters, USDOE, Office of Contractor Business, Washington, DC

T. H. Pigford, University of California, Berkeley, CA

J. Pitts, Lincoln County Courthouse, Pioche, NV

Planning Department, Nye County, Tonopah, NV

M. J. Plodinec, Savannah River Laboratory, Aiken, SC

V. Poe, Hawthorne, NV

C. Poppe, Lawrence Livermore National Laboratory, Livermore, CA

P. T. Prestholt, NRC Site Representative, Las Vegas, NV

D. L. Price, Nuclear Waste Technical Review Board, Blacksburg, VA

R. F. Pritchett, Reynolds Electrical \& Engineering Co., Inc., Las Vegas, NV

Project Directorate, U.S. Nuclear Regulatory Commission, Washington, DC

M. Revelli, Lawrence Livermore National Laboratory, Livermore, CA

J. Roberts, USDOE, Civilian Radioactive Waste Management, Washington, DC

S. Rousso, USDOE, Office of Contract Business Management, Washington, DC

S. Rousso, USDOE, Office of Program and Resources Management, Washington, DC

D. Ruffner, Lawrence Livermore National Laboratory, Livermore, CA

SAIC-T\&MSS Library, Science Applications Int. Corp., Las Vegas, NV (2)

J. D. Saltzman, USDOE, Office of External Relations, Washington, DC

J. H. Sass, U.S. Geological Survey, Flagstaff, AZ

V. R. Schneider, U.S. Geological Survey, Reston, VA

B. Selinder, Fallon, NV

Senior Project Manager for Yucca Mountain, Washington, DC

D. E. Shelor, USDOE, Office of Systems and Compliance, Washington, DC

H. D. Smith, Pacific Northwest Laboratories, Richland, WA

D. Stahl, B\&W Fuel Co., Las Vegas, NV

R. B. Stout, Lawrence Livermore National Laboratory, Livermore, CA

J. S. Stuckless, U.S. Geological Survey, Denver, CO

A. T. Tamura, USDOE, Scientific \& Technical Information, Oak Ridge, TN

Technical Information Office, USDOE, DOE Field Office, Las Vegas, NV (12)

Technical Information Center, Roy F. Weston, Inc., Washington, DC

M. ten-Brink Buchholtz, Lawrence Livermore National Laboratory, Livermore, CA

C. Thistlethwaite, Independence, $\mathrm{CA}$

T. Thornton, Babccek \& Wilcox Co., Lynchburg, VA

R. Van Konynenburg, Lawrence Livermore National Laboratory, Livermore, CA

G. Van Roekel, Caliente, NV

E. D. Verink, Nuclear Waste Technical Review Board, Gainesville, FL

B. Viani, Lawrence Livermore National Laboratory, Livermore, CA

R. V. Watkins, U.S. Geological Survey, Denver, CO

H. Weed, Lawrence Livermore National Laboratory, Livermore, CA 
C. L. West, USDOE, DOE Field Office, External Affairs, Las Vegas, NV

R. Williams, Jr., Austin, NV

C. N. Wilson, Westinghouse Hanford Co., Richland, WA

T. Wolery, Lawrence Livermore National Laboratory, Livermore, CA

T. Wood, USDOE, Civilian Radioactive Waste Management, Washington, DC

S. S. C. Wu, U.S. Geological Survey, Flagstaff, AZ

L. Younker, Lawrence Livermore National Laboratory, Livermore, CA

D. Zesiger, U.S. Geological Survey, Las Vegas, NV

J. E. Bennett, AERE Harwell Laboratory, Oxfordshire, ENGLAND

Commission of the European Communities, Brussells, BELGIUM

C. Davison, Atomic Energy Canada Ltd., Manitoba, CANADA

K. Dormuth, Atomic Energy Canada Ltd., Manitoba, CANADA

B. Grambow, Kernforschungszentrum Karlsruhe GmbH, Karlsruhe, WEST GERMANY

L. Johnson, Atomic Energy Canada Ltd., Manitoba, CANADA

R. Odoj, Institut for Chemische Technologie, Julich, WEST GERMANY

F. P. Sergent, Atomic Energy of Canada, Ltd., Manitoba, CANADA

G. Simmons, Atomic Energy Canada Ltd., Manitoba, CANADA

L. Werme, Svensk Karnbranslehantering AB, Stockholm, SWEDEN

R. Williamson, AERE Harwell Laboratory, Oxfordshire, ENGLAND 

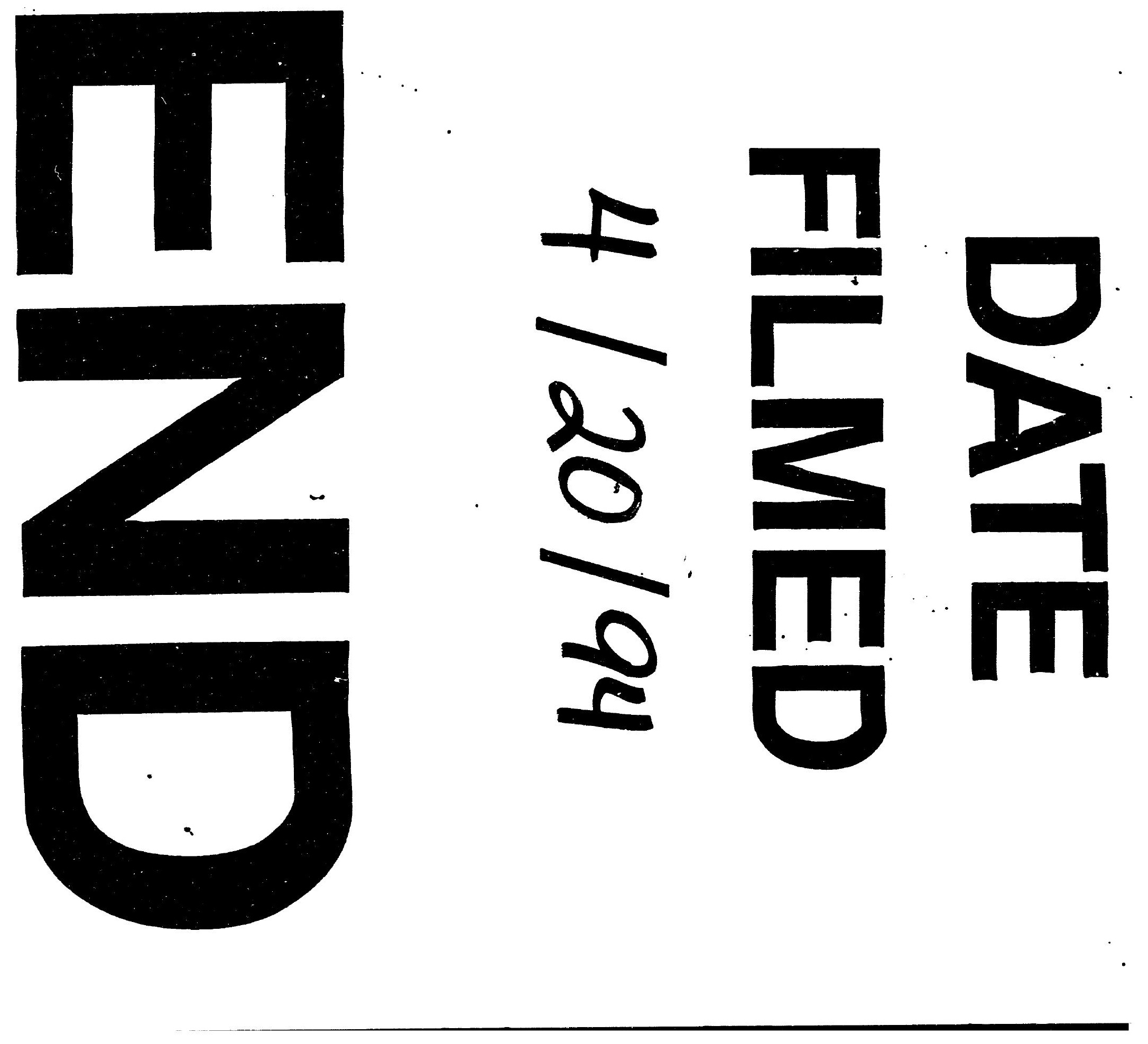

$-$ 